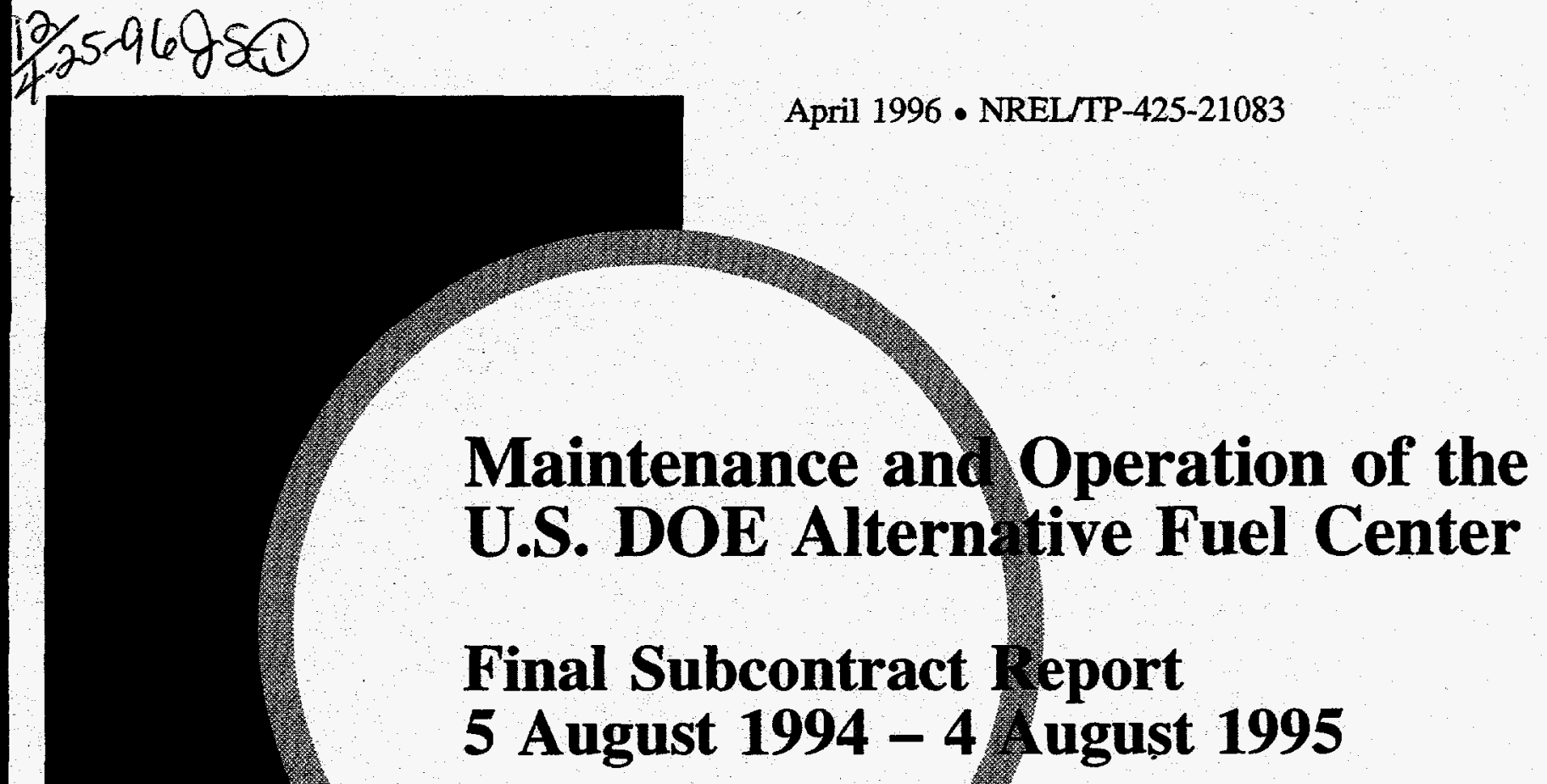

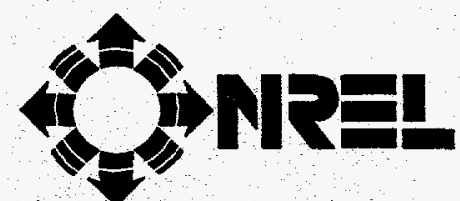

National Renewable Energy Laboratory 1617 Cole Boulevard

Golden, Colorado 80401-3393

A national laboratory of the U.S. Department of Energy Managed by the Midwest Research Institute for the U.S. Department of Energy Under Contract No. DE-AC36-83CH10093 


\title{
Maintenance and Operation of the U.S. DOE Alternative Fuel Center
}

\section{Final Subcontract Report 5 August 1994 - 4 August 1995}

\author{
J. Erwin \\ D.S. Moulton \\ Southwest Research Institute \\ San Antonio, Texas
}

NREL technical monitor:

B. Bailey

\section{NPEI}

National Renewable Energy Laboratory

1617 Cole Boulevard

Golden, Colorado 80401-3393

A national laboratory of the U.S. Department of Energy Managed by the Midwest Research Institute for the U.S. Department of Energy

Under Contract No. DE-AC36-83CH10093

Prepared under Subcontract Number XS-2-12130-1

April 1996 
This publication was reproduced from the best available camera-ready copy submitted by the subcontractor and received no editorial review at NREL.

\section{NOTICE}

This report was prepared as an account of work sponsored by an agency of the United States government. Neither the United States government nor any agency thereof, nor any of their employees, makes any warranty, express or implied, or assumes any legal liability or responsibility for the accuracy, completeness, or usefulness of any information, apparatus, product, or process disclosed, or represents that its use would not infringe privately owned rights. Reference herein to any specific commercial product, process, or service by trade name, trademark, manufacturer, or otherwise does not necessarily constitute or imply its endorsement, recommendation, or favoring by the United States govemment or any agency thereof. The views and opinions of authors expressed herein do not necessarily state or reflect those of the United States government or any agency thereof.

Available to DOE and DOE contractors from:

Office of Scientific and Technical Information (OSTI)

P.O. Box 62

Oak Ridge, TN 37831

Prices available by calling (423) 576-8401

Available to the public from:

National Technical Information Service (NTIS)

U.S. Department of Commerce

5285 Port Royal Road

Springfield, VA 22161

(703) $487-4650$ 


\title{
Executive Summary
}

\author{
Program Title: $\quad$ Maintenance and Operation of the U.S. DOE Alternative Fuel Center \\ Sponsor: $\quad$ National Renewable Energy Laboratory \\ Contract Number: $\quad$ XS-2-12130-1 \\ Project Number: $\quad 01-5151$ \\ Inclusive Dates: $\quad$ August 5, 1994 - August 4, 1995

\section{Technical Objectives}

The work in the Alternative Fuel Center(AFC) was divided into five tasks to fulfill its role in the mission of Alternative Fuels Utilization Program (AFUP) of increasing the data for alternative fuels and for improving vehicle emissions through better fuels and combustion systems. The tasks were:

Task 1: Facility maintenance for the Alternative Fuel Center of the Office of Energy Efficiency and Renewable Energy at Southwest Research Institute

Task 2: Facility upgrade: control system and hydrogen recycle flowmeter (completed in year 2)

Task 3: Other government research

Task 4: Industry research (on a noninterference basis)

Task 5: Safety and health compliance

\section{Approach}

As in years one and two of the operating contract, the duties for maintenance and coordination of the AFC hydrogenation pilot plant were arranged to respond first to AFUP work arising in the course of the year, as in the case of the luminosity study (below), and to respond as fully as possible (on a noninterference basis) to the needs of industry in the areas of alternative fuels production, analysis, and utilization. The means for making known the capability and availability of the AFC equipment and functions was by discussions at meetings, tours, and distributed publications.

\section{Accomplishments}

The maintenance of the pilot plant and fuel samples of the AFC was kept up throughout the year, while participating in several outside projects. Equipment wear and tear generated in the course of those outside projects was repaired and parts purchased through each participating project, saving AFC project funds for more long-term enhancement of capabilities.

An AFUP investigation this year included experiments of flame luminosity for mixtures of ethanol and methanol. Both neat alcohols and three intermediate blends were burned in controlled tests to rate flame brightness. Methanol was assigned a brightness rating of 1 and ethanol was assigned 10 . The ethanol dominates the flame luminosity as shown in the figure below. 
An initiative was the addition of a new, approximately 1.6 liter, small reactor in parallel with the existing reactor train. The smaller volume permits quicker changes in operating condition, thus being conducive to scoping studies in preparation for work in the larger reactors or for calculations of process parameters. The small reactor flowrates were too low for the existing stripper/still, so the stripper preheater was modified to serve double duty as a small stripper for the new reactor, as well as, its usual preheating for the main stripper/still.

Another augmentation of capabilities was the addition of flow meters to increase the resolution of overall and elemental mass balances. Three flowmeters were installed to collect data to use with gas analyses in the calculation of hydrogen solubility

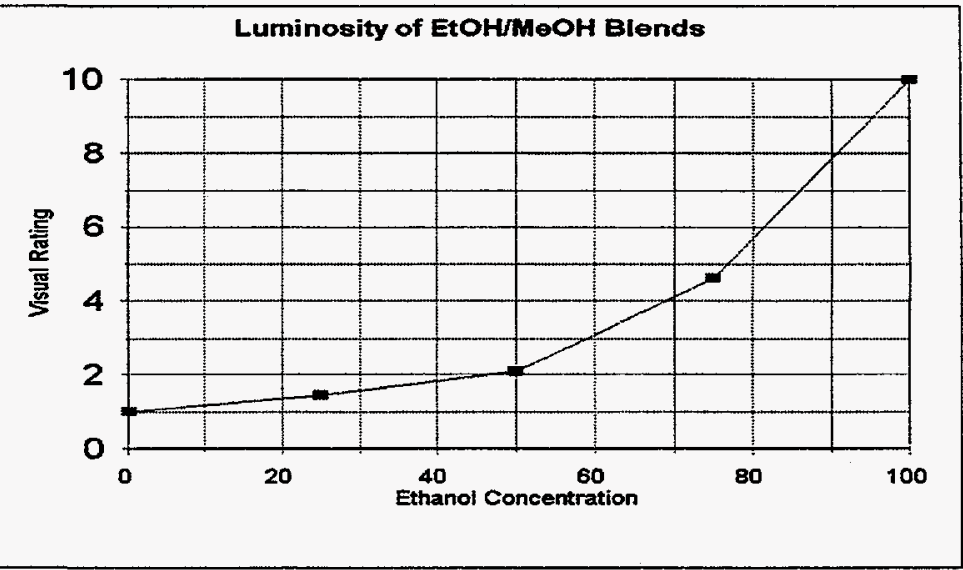
loses and calculation of heteroatom balances. This upgrade of the mass balances used the full capabilities of the new operating software in the hydrogenation pilot plant.

The data collections were also used to create operating timelines of process variables through the course of processing runs. These plots give an overview of the entire run and can be combined with product measurements to chart product quality. The plot below is a timeline from a recent run.

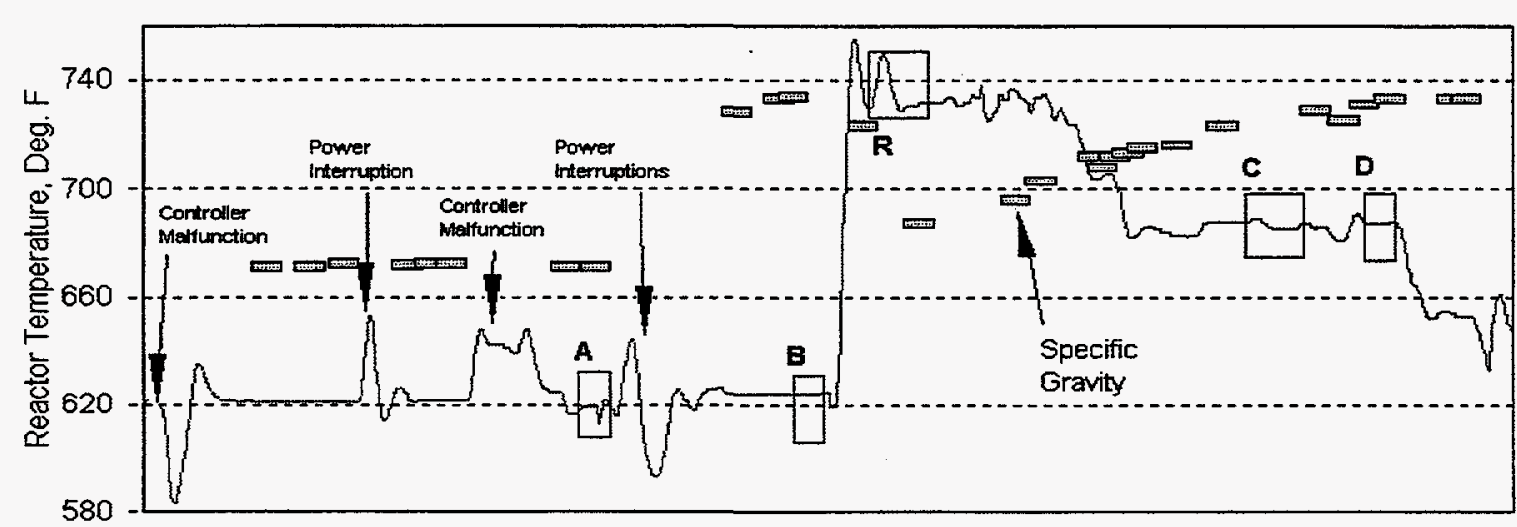

0.94 0.92 0.90 0.88 0.86 0.84
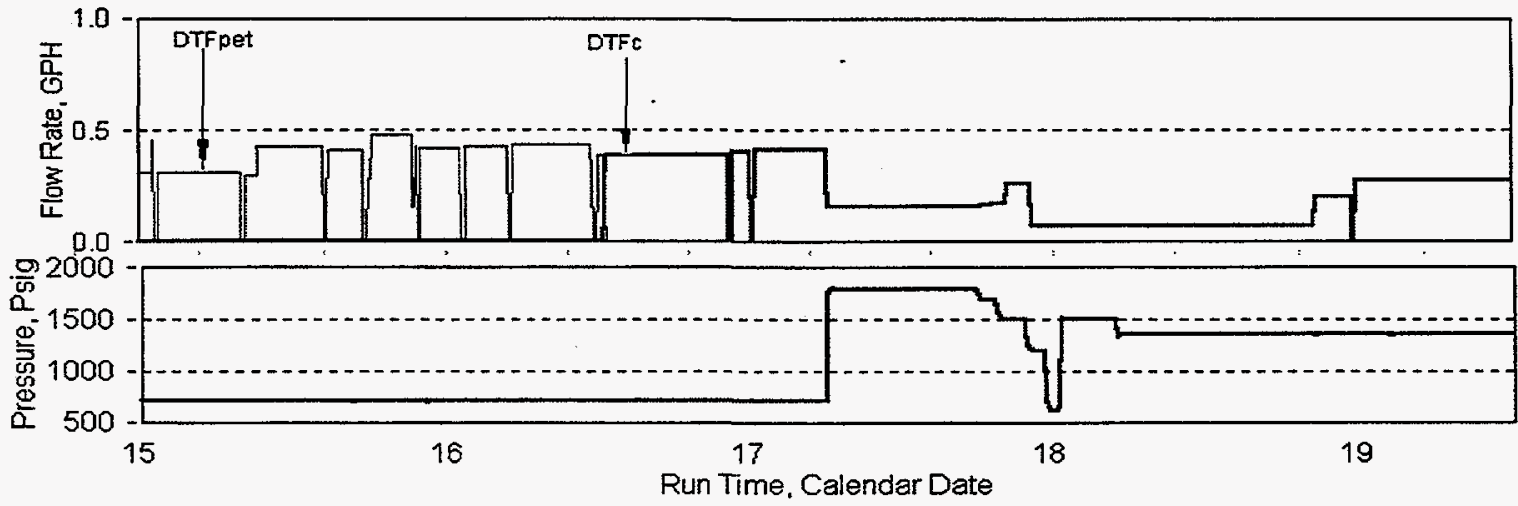


\section{Contents}

Introduction $\ldots \ldots \ldots \ldots \ldots \ldots \ldots \ldots \ldots \ldots \ldots \ldots \ldots \ldots \ldots \ldots \ldots \ldots \ldots \ldots \ldots \ldots$

Task 1: Facility Maintenance $\ldots \ldots \ldots \ldots \ldots \ldots \ldots \ldots \ldots \ldots \ldots \ldots \ldots \ldots \ldots \ldots \ldots$

Additional Reactor . . . . . . . . . . . . . . . . . . $5 \ldots \ldots \ldots \ldots \ldots$

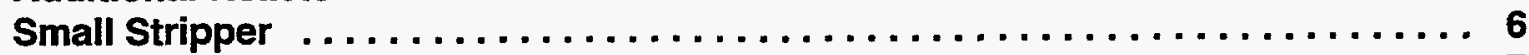

Mass Balance ............................ 7

Ethanol/Methanol Flame Luminosity $\ldots \ldots \ldots \ldots \ldots \ldots \ldots \ldots \ldots \ldots \ldots \ldots$

Task 2: Facility Upgrade $\ldots \ldots \ldots \ldots \ldots \ldots \ldots \ldots \ldots \ldots \ldots \ldots \ldots \ldots \ldots \ldots$

Tasks 3 and 4: Other Government and Industry Research . . . . . . . . . . . 15

Refining and End Use Study of Coal Liquids ................. 15

Effect of Refining Severity on Lubricity of NATO F76 Fuel $\ldots \ldots \ldots \ldots \ldots \ldots \ldots 17$

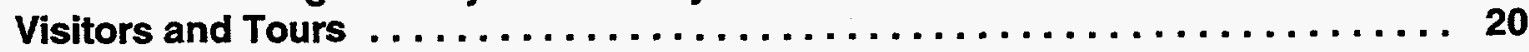

Task 5: Health and Safety Compliance $\ldots \ldots \ldots \ldots \ldots \ldots \ldots \ldots \ldots \ldots \ldots \ldots$

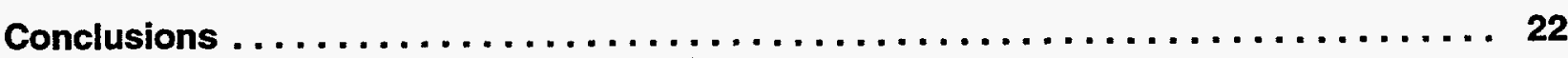

Exhibit 1. Index of Monthly Progress Reports ..................... 23

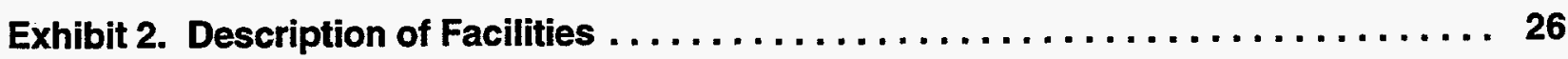

Exhibit 3. Annual Government Property Inventory . . . . . . . . . . . . . 30 


\section{List of Figures}

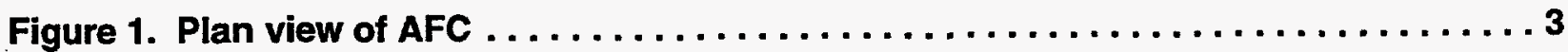

Figure 2. Modifications to AFC hydrogenation pilot plant $\ldots \ldots \ldots \ldots \ldots \ldots \ldots \ldots, 5$

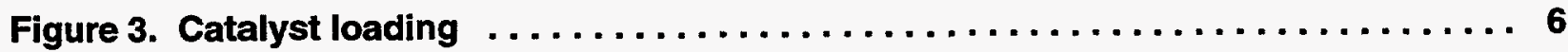

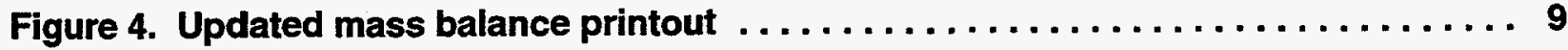

Figure 5. Timeline from pilot plant processing $\ldots \ldots \ldots \ldots \ldots \ldots \ldots \ldots \ldots \ldots \ldots$

Figure 6. Flame luminosity of ethanol/methanol mixtures $\ldots \ldots \ldots \ldots \ldots \ldots \ldots, 13$

Figure 7. Organization of End Use Study work $\ldots \ldots \ldots \ldots \ldots \ldots \ldots \ldots \ldots \ldots \ldots \ldots$

\section{List of Tables}

Table 1. Extremes in Available Process Conditions $\ldots \ldots \ldots \ldots \ldots \ldots \ldots \ldots \ldots$

Table 2. Summary of AFC Monthly $\log \ldots \ldots \ldots \ldots \ldots \ldots \ldots \ldots \ldots \ldots \ldots \ldots \ldots$

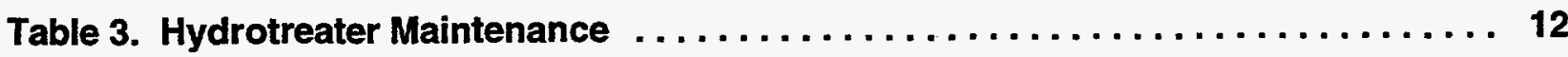

Table 4. AFC Fuels and Fuel Components in Storage .................. 12

Table 5. Summary of AFC Processing Runs $\ldots \ldots \ldots \ldots \ldots \ldots \ldots \ldots \ldots \ldots \ldots \ldots \ldots \ldots \ldots$

Table 6. Fuel Samples in Navy Lubricity Study $\ldots \ldots \ldots \ldots \ldots \ldots \ldots \ldots \ldots \ldots \ldots \ldots$

Table 7. Tours and Visits to DOE Alternative Fuel Center $\ldots \ldots \ldots \ldots \ldots \ldots \ldots 20$ 


\section{Introduction}

The Alternative Fuel Center (AFC) was established by the U.S. Department of Energy (DOE) as part of the Alternative Fuels Utilization Program (AFUP) to provide drum quantities of finished transportation fuels from a variety of sources. Since 1978, the AFUP of the Office of Energy Efficiency and Renewable Energy has investigated the possibilities and limitations of expanded scope of fuel alternatives and replacement means for transportation fuels from alternative sources to complement conventional petroleum fuels. The main function was to provide test fuels in 5- to 500-gallon quantities for research projects on the utilization of alternative fuels.

DOE funded the design, construction, and installation of a hydrogenation pilot plant capable of performing a range of hydrotreating, reforming, and hydrocracking operations. Southwest Research Institute (SwRI) provided the building, utilities, and laboratory and safety systems needed for the pilot plant. Later, the U.S. Navy provided a pilot-scale continuous distillation unit, and SwRI provided batch distillation equipment, which are conveniently housed in the same building as the hydrotreater pilot plant, but are not formally part of the Alternative Fuel Center (AFC). A plan view drawing of the AFC is shown in Figure 1.

The AFUP is part of the Alternative Fuels Utilization Program, which includes research, development, and demonstration of alternative fuel vehicle (AFV) technologies and is managed at the National Renewable Energy Laboratory (NREL) in Golden, Colorado. ${ }^{1}$ The AFC work reported here contributes to the two primary objectives of the AFUP: (1) data for alterative-fuel-capable vehicles to enhance our energy security and (2) data for controlling emissions for improved air quality. At present the synergy with the objectives of outside projects going on in the AFC is the principal category of operation.

As pointed out in the NREL report, having the capability to use and rely on domestic fuel resources benefits the balance-of-trade deficit and strengthens the national economy. In addition, the United States national security interests outside the United States are reduced. Research and development of alternative fuel utilization technology increased competition to transportation fuel markets and advanced technologies for conventional transportation fuels, as well as alternative fuels themselves. The availability of alternative fuels sets a theoretical ceiling on conventional transportation fuel prices. By strengthening our alternative fuel utilization capability, the United States strategic and economic strengths increase.

Alternative fuels have improved the environment. Organic emissions from most alternative fuels have lower reactivity in the atmosphere compared to emissions from conventional transportation fuels. Results include less low-altitude ozone being formed, which results in cleaner air. There are also benefits for some alternative fuels which produce less emissions of nitrogen oxides, that can also contribute to urban ozone formation. Particulate emissions are generally lower for alternative fuel vehicles.

The goal of AFUP research and development at NREL is to develop light-duty and heavy-duty vehicle and fuel utilization technologies that will be commercially superior to technologies that rely on conventional, petroleum-derived transportation fuels. The reference for development is a point in the future when new

${ }^{1}$ Alternative Fuels Utilization Program 1995 Annual Report, NREL Report No. MP-425-8301, Prepared by National Renewable Energy Laboratory, Golden, Co. 
technology will be developed and become commercial. This assumes that commercial technology being used today will advance, so AFUP objectives must meet or exceed the anticipated improvements. Utilization technology includes 1) methods for enhancing fuel formulation, 2) fuel storage and handling, 3) engine and vehicle performance, and 4) emissions profiles. AFUP does not address directly resource availability, resource recovery, resource processing, or resource economics, but it assumes that resources are available. Nevertheless, utilization technology must consider every avenue to conserve primary resources as a means of achieving program goals and improving commercial competitiveness. Energy efficiency (i.e., fuel economy) is therefore of prime importance for all alternative fuel options. Alternative fuels investigated in the AFUP include methanol, ethanol, natural gas, liquefied petroleum gas (LPG), hydrogen, fuel ethers, and other renewable fuels that may be derived from biomass. Reformulated gasoline and modern diesel fuel are also included in the program as baselines against which alternative fuel performance may be compared.

The NREL AFUP works, under the direction of DOE, with industry, other government agencies, universities, and coalitions to coordinate and improve the research program. Multiplication of results often occurs from programs in which AFUP resources are combined with resources of collaborating organizations to work on common objectives. Data from the Alternative Motor Fuels Act (AMFA) and the Energy Policy Act of 1992 (EPACT) programs are stored in the DOE Alternative Fuels Data Center housed at NREL. The AFC is available to participate in all of these efforts.

This report covers the third year of the current contract. AFC objectives were accomplished under the following five tasks:

Task 1: Facility maintenance

Task 2: Facility upgrade

Task 3: Other government research

Task 4: Industry research

Task 5: Safety and health compliance. 


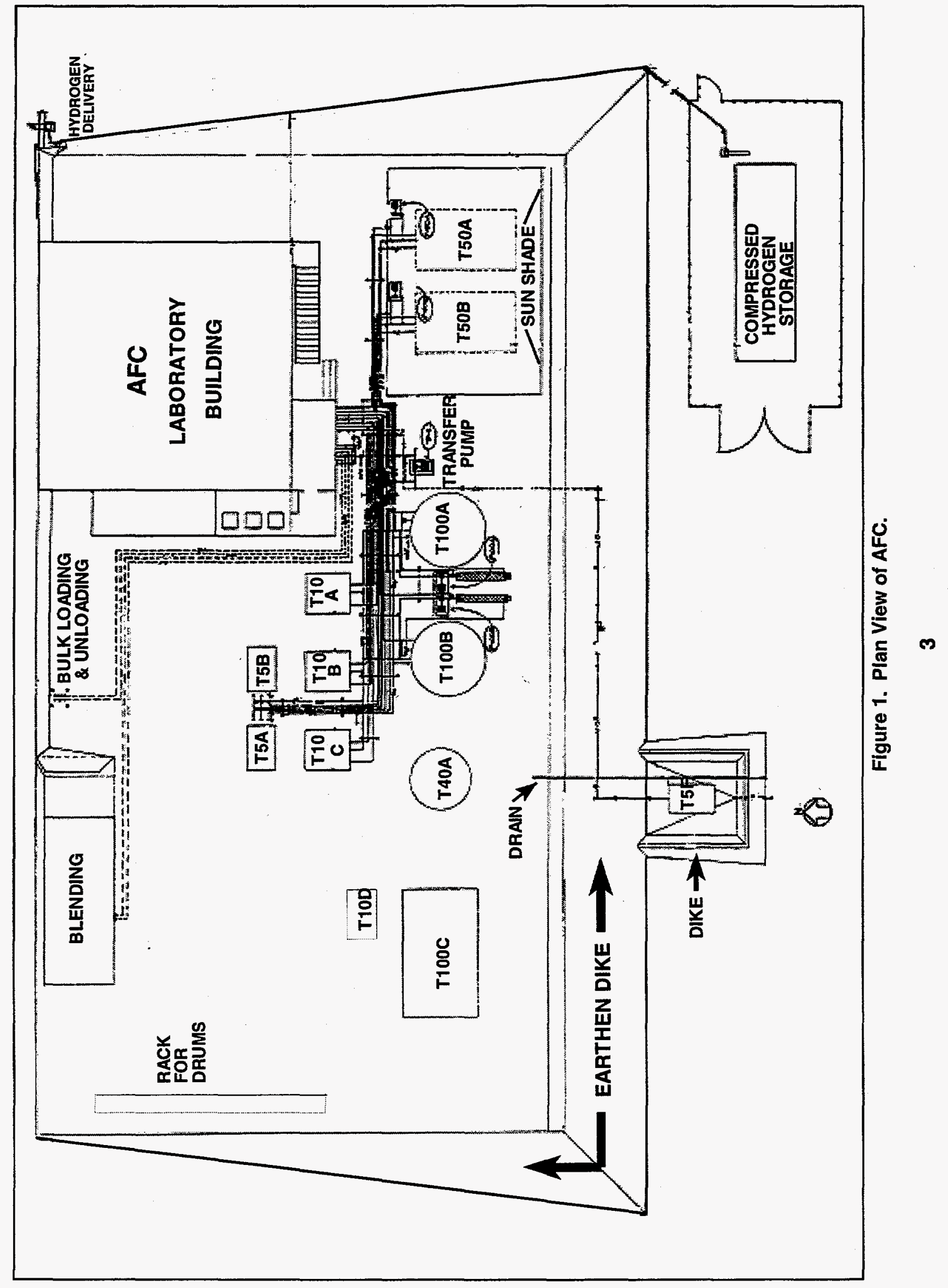


The greatest amount of work this year was for other government projects, although there was some commercial work. The main projects are discussed in the section for Tasks 3 and 4. Equipment upgrades included a new, small reactor and several flow meters. The small reactor permits rapid changes among operating conditions and requires less feed liquid for scoping studies and trial runs. The resulting array of accessible conditions is presented in Table 1.

The additional flowmeters allow more detailed and more accurate mass balances to be made around and within the hydrogenation unit. With the new data and appropriate gas analyses, heteroatom balances can be calculated and hydrogen loses can be measured. These topics are discussed in more detail under Task 2 .

Each of the five tasks are discussed in the following sections. A table summarizing the monthly progress reports is provided in Exhibit 1.

Table 1. Extremes in Available Process Conditions

\begin{tabular}{|c|c|c|c|c|c|c|c|c|}
\hline \multicolumn{4}{|c|}{ Parameter } & Device & Units & Max & Min & Sensor \\
\hline \multicolumn{4}{|c|}{ Multizone Temperature } & $\begin{array}{l}\text { FRN101 } \\
\text { FRN201 }\end{array}$ & ${ }^{\circ} \mathrm{F}$ & $\sim 950$ & 280 & $\begin{array}{l}\text { TE107-111 } \\
\text { TE207-211 }\end{array}$ \\
\hline \multirow{2}{*}{\multicolumn{4}{|c|}{ Liquid Flow }} & P51A & \multirow{2}{*}{ GPH } & 3.0 & 0.1 & WT51A \\
\hline & & & & P51B & & 1.6 & 0.1 & WT51B \\
\hline & & & & Total & $\mathrm{BblPH}$ & 0.109 & 0.0024 & Calculation \\
\hline \multirow{4}{*}{$\begin{array}{c}\text { Vessel } \\
\text { Gal }\end{array}$} & Vessel & Empty & Packed & \multirow{4}{*}{ LHSV } & \multirow{4}{*}{$\mathrm{Hr}^{-1}$} & & & \multirow{4}{*}{ Calculation } \\
\hline & $G+R$ & 2.15 & 1.56 & & & 2.9 & 0.06 & \\
\hline & $R$ & 1.16 & 1.05 & & & 4.4 & 0.09 & \\
\hline & Small & 0.507 & 0.38 & & & 23 & 0.5 & \\
\hline \multicolumn{4}{|c|}{ Pressure } & PCV121 & PSIG & 2500 & $400^{*}$ & PT101 \\
\hline \multirow{2}{*}{\multicolumn{4}{|c|}{ Hydrogen Flow }} & C11 & \multirow{2}{*}{ SCFH } & 75 & 0 & FT21A \\
\hline & & & & C121 & & 250 & 25 & FT21B \\
\hline \multicolumn{4}{|c|}{ Contacting Rate } & - & SCFB & $>5000$ & 230 & Calculation \\
\hline
\end{tabular}




\section{Task 1: Facility Maintenance}

The AFC comprises of samples, structures, equipment, and the storage infrastructure on a specially diked work area spread over about an acre at SwRI. Descriptions of the facilities are in Exhibit 2 at the end of this report.

Modifications to the hydrotreater pilot plant have increased its utility and made it more versatile. The changes, made in response to the needs of non-AFUP projects, provide benefits for all subsequent work, including AFUP processing:

An additional, small reactor and heat exchanger to streamline trial runs, or 'scoping studies', for limited quantities of feed stocks or unusual processing conditions

A modification in the distillation section to make sampling faster and more representative when operating the small reactor

The installation of gas meters to provide greater accuracy and detail for the mass balances.

\section{Additional Reactor}

Sections of the updated flow diagram, Figure 2 , highlighted with hash marks, denote the recent modifications and new equipment. These changes were made with flexibility in mind to preserve all original functions, while providing for new purposes.

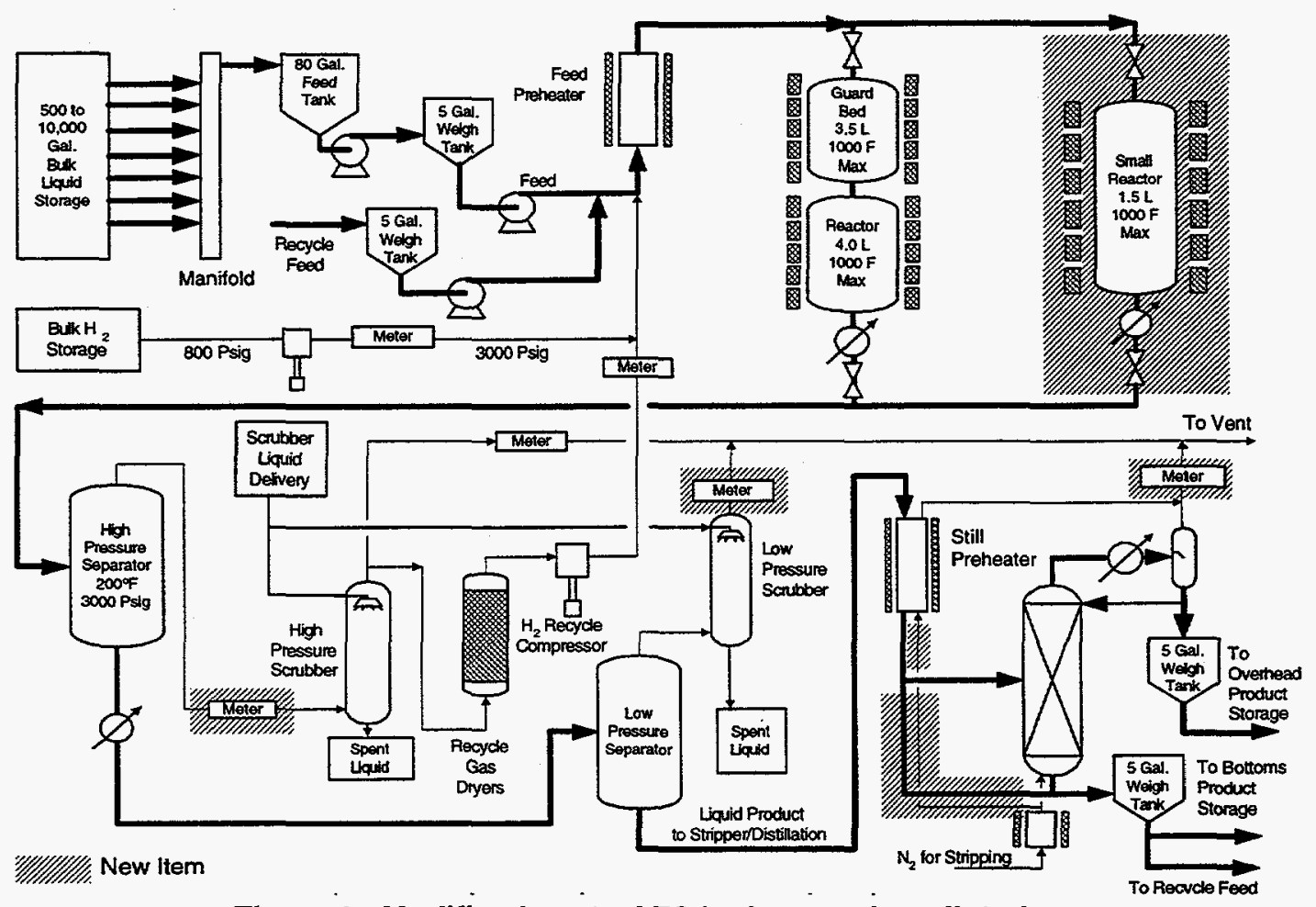

Figure 2. Modifications to AFC hydrogenation pilot plant 
The new reactor was small-sized relative to both the distillation column capacity, and the product cooler. The two inch I.D. distillation column, holding a large volume compared to about 0.25 gallons per hour rate typically used with the small reactor, caused a long delay between the reactor exit and the sample port. Since some back-mixing naturally occurs in the column, obtaining a representative, steady-state sample often required several additional hours after completing a change of reactor parameters. The delay caused the use of excessive experiment time, while operators waited for the changes in product quality to go through stripping for sour gas removal and arrive at the sample port. Sampling ahead of the column, and removing the sour gases by caustic washing, proved unsatisfactory, because, in the presence of air, some reversal of the de-sulfurizing reactions occurred. Avoiding the problem with complete nitrogen blanketing during the whole procedure was cumbersome.

The new reactor, 81 inches long by 1.503 inches internal diameter, contains 0.622 gallons (2.36 liters) total volume. The upper section, 17 inches, packed with inert, tabular alumina provides internal heating, and three inches at the bottom provides catalyst support and initial product cooling, leaving 61 inches for active catalyst. The catalyst volume, 0.423 gallons ( 1.60 liters), allows production of small samples made the same way larger samples can be made, with both large and small reactors using reactor geometries resembling those used commercially. As shown in the loading diagram, Figure 3 , the bed currently contains a 50 volume percent mixture of active catalyst and tabular alumina, so the active volume is 0.21 gallons ( 0.80 liters). In addition to conserving feed stocks in conventional operation, the small reactor facilitates exploration of unusually high space velocities, up to 12 liquid hourly space velocity (LHSV) with the current catalyst packing and feed pump.

\section{Small Stripper}

Changes made in the distillation section solved the problem, providing the versatility to accommodate both large and small flow rates. The still pre-heater was modified to perform the additional function of stripper for low flow rates, and a by-pass was installed around the column to the sampling port and the bottoms product tank. Coke had built up in the old one-half inch pre-heater tube, and it was replaced with a new three-quarter inch tube filled with Poropak ${ }^{\circledR}$ poured column packing to provide the surface area needed for effective stripping of the sour gases. Even with the packing in place, the larger diameter readily accommodates the flow rates used with the large reactor and the distillation column, and the packing gives better heat transfer. For the small reactor, a nitrogen line with a 'J-tube' to keep a liquid level in the bottom of the column in the stripper mode, routes stripping gas back through the pre-heater rather than forward to the product weigh tank. The column pre-heater now functions well as a pre-heater, but making minor changes in the flow paths convert it for use as a small-flow stripper.

\section{Small Reactor}

\begin{tabular}{|c|}
\hline \\
Initial Heating \\
16.88 In., $829 \mathrm{~g}$. \\
Tabular Alumina \\
(Inactive) \\
\\
\\
\\
\\
\\
Equilibrium Catalyst, \\
American Cyanamid HDN-60 \\
$1 / 16$ In. Tri-lobe Extrudates \\
20.5 Wt.\% MoO3 \\
5.0 Wt.\% NiO \\
(Before Sulfiding) on \\
Active Alumina \\
801 g., 0.2114 Gallons \\
Catalyst (mixed with equal \\
volume tabular alumina) \\
Height: 60.5 Ins. \\
\hline \\
\hline Bottom, 3.00 In. \\
\hline g. Tab. Alumina \\
\hline
\end{tabular}

Figure 3. Catalyst loading 
A new product cooler was purchased for use only with the small reactor. It was a Parker-Hannifin counterflow heat exchanger, coiled to form a helix, with the product flowing through an inner, stainless-steel tube, and cooling water flowing in the annular space between the inner tube and an outer, copper tube. Installation beneath the small reactor, and its configuration, facilitates draining of the heat exchanger and reactor.

\section{Mass Balance}

Mass balances give useful information to operators and engineers both during hydrotreater operation, and for post-run analyses. When the hydrotreater was initially constructed, the gas metering and analysis system accounted for the major gas flows, and the other flows were small enough to be lumped into other streams for most work. The major gas flows included the feed hydrogen, the recycle gas after scrubbing and drying, and the portion of gas from the high-pressure scrubber that went to the vent. In addition, stripping gas and vent gas were each monitored for the column, so hydrocarbon light ends losses could be estimated from the difference in the two flow rates.

The original system did not account for the gas volumes absorbed during scrubbing and drying. The absorbed volumes intentionally included the sour gases, hydrogen sulfide and ammonia, but this prevented obtaining sulfur and nitrogen balances. A new flow meter now provides the additional information required. The orifice-plate meter measures the total flow out of the high-pressure separator, which should equal the recycle plus high-pressure vent gas flows, plus the scrubbing and drying losses. With a gas analysis at this point, the mass balance calculations can account for the sulfur and nitrogen gases, and provide the corresponding elemental balances. The sampling point hardware was already in place.

The other two new meters provide increased accuracy to the overall balance. The new meter on the lowpressure vent gas accounts for that relatively small quantity, and the new meter on the still vent replaces an older instrument which had worn out and become inoperable.

The on-line mass balance calculation requires access to previously recorded data. Xytel Corp. updated our data retrieval program to include several additional variables, allowing us to use the new flow-meters in the customary way for the on-line mass balance calculation. The new printout, Figure 4 , provides nitrogen and sulfur balances, as well as a separate accounting for the high- and low-pressure gas flows, instead of the combined 'HP/LP gas' previously reported.

The overall computer upgrade, put into place last year, now provides easier access to historical process data for analysis than did the old computer system. The new data format allows convenient importing into spreadsheets for post-run graphing, calculating related values, or statistical analyses. The data collection repeats at short intervals so the resulting record displays the processing history in detail. As an example, Figure 5 shows a processing time-line obtained during work on the End Use Study described below. The squares indicated by the block letters give the time intervals used for mass balance calculations (not shown), and the terms DTFpet and DTFc indicate different feed stocks. Note that the feed flow rate, based on feed-tank weight loss, occasionally indicated zero due to the temporary period of weight gain during tank refill.

The hydrotreater modifications provided major, new capabilities at modest cost. The Institute provided the new reactor and the associated furnace at no cost to the project. These two items had been purchased several years ago for about $\$ 20,000$, intended for use on a project that never came about. The reactor had not been used previous to this installation. A simple changing of thermocouple connections allows using the large reactor temperature controller for the small reactor, so a new controller was not required. The product cooler $(\$ 1200)$ and the new meters $(\$ 2300)$ were purchased with project funds designated for parts, and the project 
also funded the program modification giving increased access to the historical data base ( $\$ 500)$. Modifications to the distillation section required only inexpensive items which were mostly on-hand.

In summary, as a result of changes made this year, the following new capabilities have been added at minimal project cost:

- Scoping studies at low flow rates, typically 0.25 gallons per hour, using the same conditions, if desired, as available at the higher rates (up to about 4 gallons per hour)

- With preferred reactor geometry, maximum specific processing rate to 12 LHSV (up from 2.8 ), useful for reactions occurring faster than most conventional petroleum processing

- Provision for sulfur and nitrogen mass balances

- Improved accuracy of overall mass balances.

\section{Maintenance and Custody}

The continuing work of maintaining the hydrogenation pilot plant is carried out during all operations of the equipment - on AFC duties and outside work. A benefit of the outside work is the exercise it provides to the equipment an replacement of worn and outdated parts. Occasionally, upgrades are obtained in this manner. The environment of the equipment is maintained also as reflected on the monthly inspection log of Table 2 . The detection equipment discrepancies noted there would not routinely be corrected with project funds, and recently a plan for reinstating these monitoring devices was worked out and funding identified.

The more notable repair actions on the hydrotreater equipment are listed in Table 3. Items marked with an asterisk were funded on outside work as were replacements of small items and replaceables (gaskets, rupture disks, fuses, etc).

In August, 1995, an inventory of AFC test fuels and components in storage was performed. AFC project materials (with brief descriptions) are listed in Table 4, including those AFC materials used in earlier AFC operating contracts. 
RUN NO: 52-5

MASS EALANCE: REPORT FOR: MO. 1 DaY 25 Year 95 Time $8: 30$ Starting the above time and continuing 1380 MINS

FEED/DESC. FL-2285, OLE, MNEC

FEEDS
LIQUID HC
FEED H2
TOTAL FEED
PRODUCTS
HPAL GAS
FRACT GAS
RECYCLE GAS
OHD LIQUID
BTMS LIQUID
RECYCLE LIQUID
TOTAL PRODUCTS
GAIN/LOSS

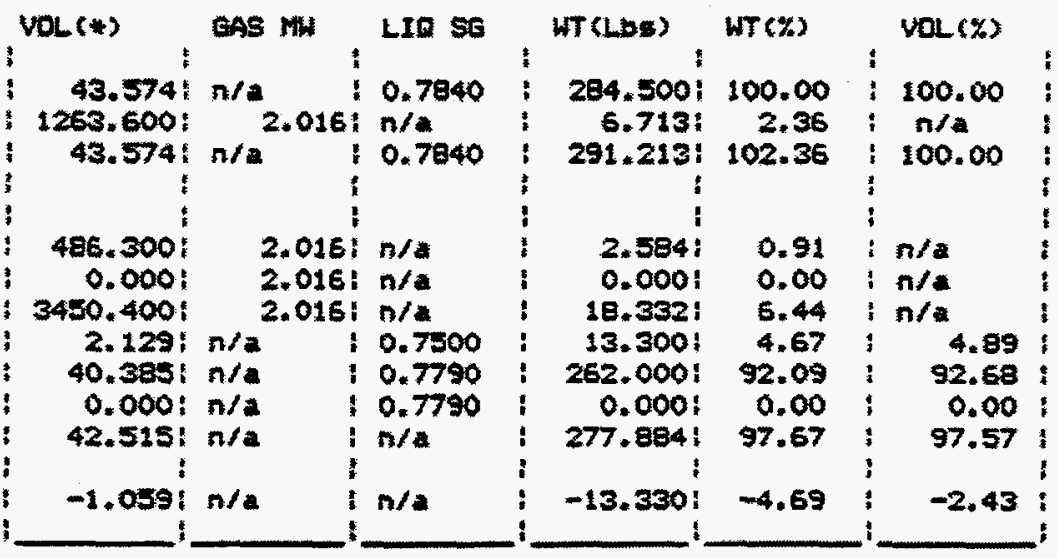

HYDROEEN BALANCE HYDROBEN FEED HPILP EAS OUT FRACT EAS OUT H2 RECYCLE GROSS H2 COMSUMED

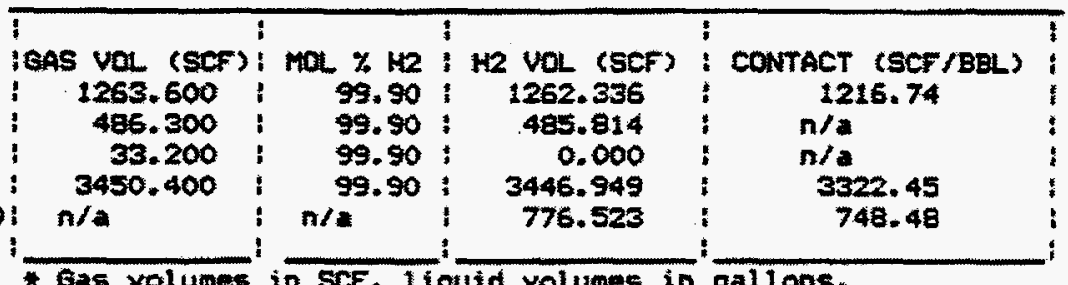

GAS BALANCE

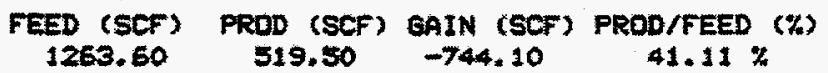

OPERATINE CONDITIONS SUMMARY:

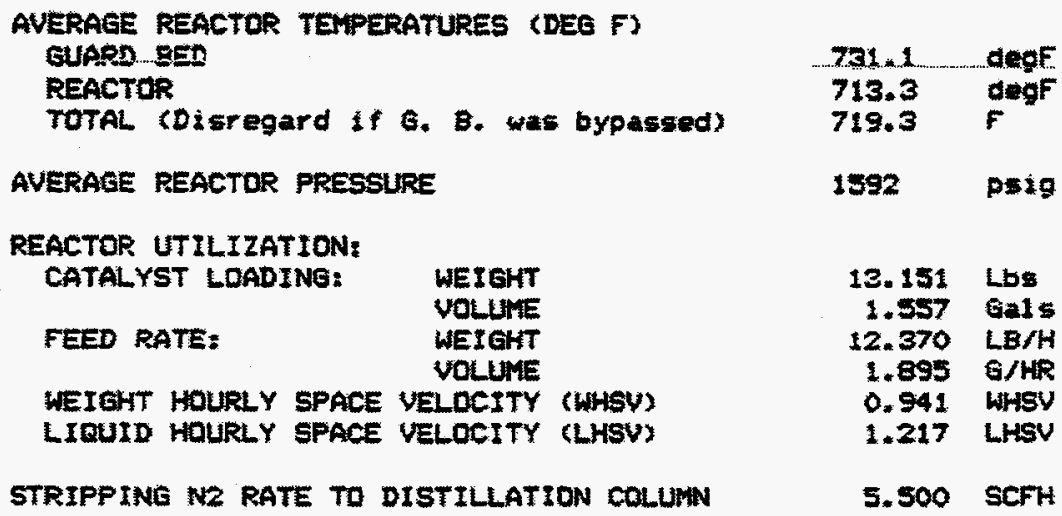

Nore: This report was printed at $12: 23: 16$ on 01-27-95.

Figure 4. Updated mass balance printout 


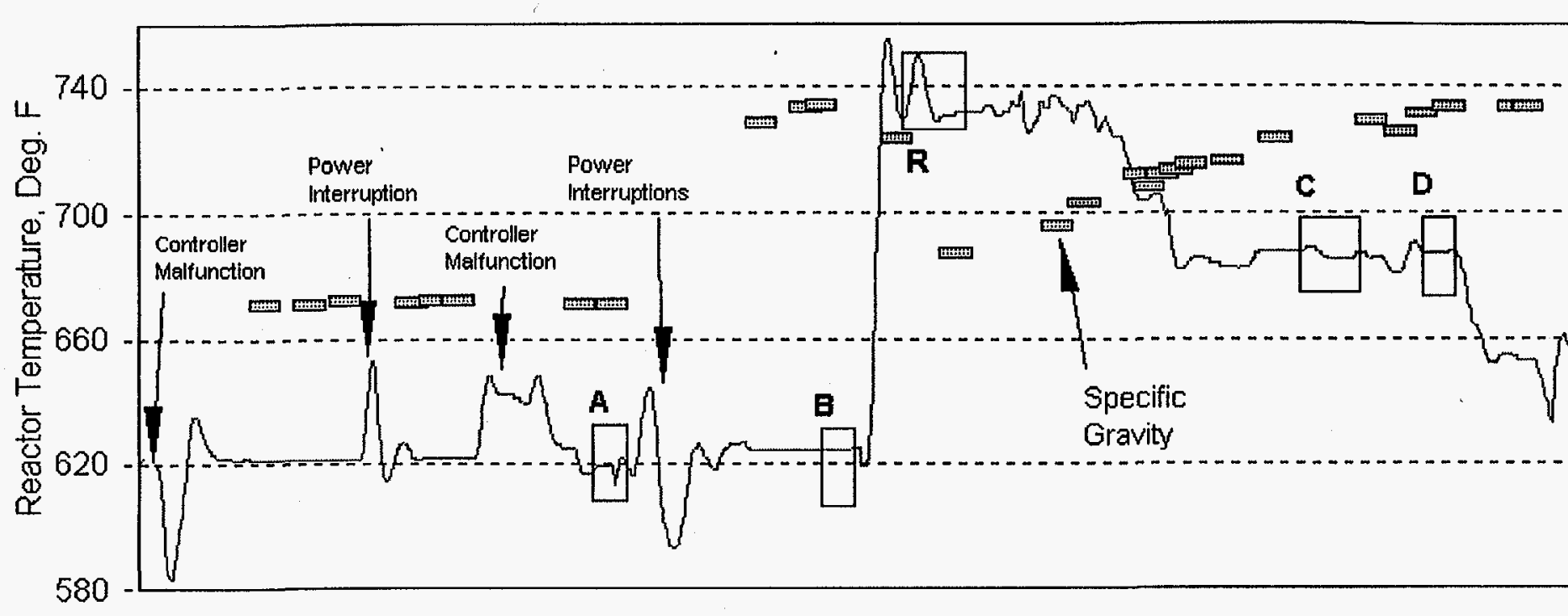

0.94
0.92
0.90
0.88
0.86
0.84
0.82
0.80
0.78
0.76
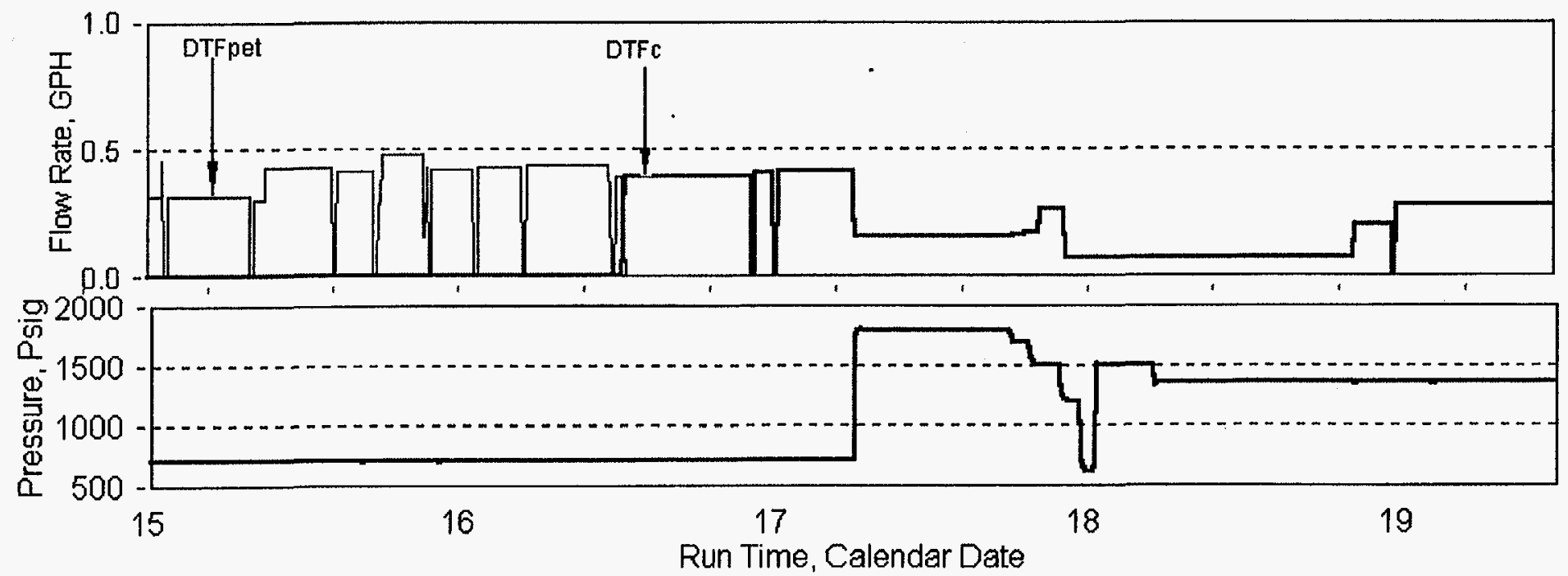

Figure 5. Timeline from pilot plant processing 
Table 2. Summary of AFC Monthly Log

\begin{tabular}{|c|c|c|c|c|c|c|c|c|c|c|c|c|c|}
\hline Function & Aug 94 & Sep 94 & Oct 94 & Nov 94 & Dec 94 & $\operatorname{Jan} 95$ & Feb 95 & Mar 95 & Apr 95 & Mav 95 & Jun 95 & Julv 95 & Aug 95 \\
\hline Fire \& Smoke Detectors & 1 & 1 & 1 & 1 & 1 & 1 & 1 & 1 & 1 & 1 & 1 & 1 & 1 \\
\hline Gas Alarms & 234 & 234 & 234 & 234 & 234 & 234 & 234 & 234 & 234 & 234 & 234 & 234 & 234 \\
\hline Air Filters & $x$ & $x$ & $x$ & $x$ & $x$ & $x$ & $x$ & $x$ & $x$ & $x$ & $x$ & $x$ & $x$ \\
\hline Air \& Water Systems & $x$ & $x$ & $x$ & $x$ & $x$ & $x$ & $x$ & $x$ & $x$ & $x$ & $x$ & $x$ & $x$ \\
\hline Emergency Lights & $x$ & $x$ & $x$ & $x$ & $x$ & $x$ & $x$ & $x$ & $x$ & $x$ & $x$ & $x$ & $x$ \\
\hline Lower Revetment & $x$ & $x$ & $x$ & $x$ & $x$ & $x$ & $x$ & $x$ & $x$ & $x$ & $x$ & $x$ & $x$ \\
\hline Hydrogen Trailer & $\mathrm{x}$ & $x$ & $x$ & $x$ & $x$ & $x$ & $x$ & $x$ & $x$ & $x$ & $x$ & $x$ & $x$ \\
\hline Oil Traps & $x$ & $x$ & $x$ & $x$ & $x$ & $x$ & $x$ & $x$ & $x$ & $x$ & $x$ & $x$ & $x$ \\
\hline Upper Revetment & $x$ & $x$ & $x$ & $x$ & $x$ & $x$ & $x$ & $x$ & $x$ & $x$ & $x$ & $x$ & $x$ \\
\hline Tank Inspections & $\mathrm{X}$ & $x$ & $x$ & $x$ & $x$ & $x$ & $x$ & $x$ & $x$ & $x$ & $x$ & $x$ & $x$ \\
\hline
\end{tabular}

\#1 Mainbay smoke detector not working \#2 Combustible gas detector failed

\#3 H2S detector failed

\#4 Hydrogen sensor

$x$ checked and or verified 
Table 3. Hydrotreater Maintenance

\begin{tabular}{l|l|l|l}
\hline Item & Date & Description & Cost \\
\hline 1 & Aug 94 & Repacked HV430 & $50^{*}$ \\
\hline 2 & Aug 94 & Rebuilt preheater 401 & $100^{*}$ \\
\hline 3 & Oct 94 & Replaced PT81 & $250^{*}$ \\
\hline 4 & Oct 94 & Rebuilt PCV121 & $100^{*}$ \\
\hline 5 & Nov 94 & Replaced LT91B & $1029^{*}$ \\
\hline 6 & Nov 94 & Replaced 3 TC's in Rx & $200^{*}$ \\
\hline 7 & Nov 94 & Replaced Brain Board & $213^{*}$ \\
\hline 8 & Apr 95 & Rebuilt feed pumps P51A,P51B & 1100 \\
\hline 9 & Aug 95 & Install new flow meters FT82, FT91, FT401 & 2287 \\
\hline
\end{tabular}

Table 4. AFC Fuels and Fuel Components in Storage

\begin{tabular}{l|c|c|l}
\hline $\begin{array}{l}\text { SwRI } \\
\text { ID No. }\end{array}$ & Product Type & $\begin{array}{c}\text { No. of } 55 \text { Gal. } \\
\text { Drums }\end{array}$ & \multicolumn{1}{|c}{ Description } \\
\hline FL-1309 & Middle Distillate & 1 & High nitrogen shale oil hydrotreated in Run 10 \\
\hline FL-1330 & Oil & 1 & Paraho shale oil blend \\
\hline FL-1393 & Naphtha & 1 & Wilsonville coal liquid hydrotreated in Run 12 \\
\hline FL-1418 & Naphtha & 1 & Wilsonville coal liquid hydrotreated in Run 13 \\
\hline FL-1440 & Oil, DF range & 5 & Coker gas oil from Texaco \\
\hline FL-1442 & Oil, DF range & 0.5 & Low sulfur, light coker gas oil htd in Run 14 \\
\hline FL-1443 & Oil, DF range & 1 & Low arom, light coker gas oil htd in Run 14 \\
\hline FL-1538 & Oil, DF range & 1 & Light cycle oil \\
\hline FL-1615 & Oil, DF range & 1 & Low sulfur, light cycle oil, hydrotreated \\
\hline FL-1627 & Diesel fuel & 13 & Straight run, petroleum derived \\
\hline FL-1840 & Diesel fuel & 1 & Fischer-Tropsch Diesel \\
\hline FL-1873 & Diesel fuel & 1 & Low aromatics, htd, straight run diesel \\
\hline FL-1932 & Oil & 23 & Paraho shale oil \\
\hline FL-2028 & Naphtha & 2 & FCC product, hydrotreated in Run 26 \\
\hline FL-2032 & FCC naphtha & 6 & FCC product \\
\hline FL-2062 & Naphtha & 2 & FCC product, hydrotreated in Run 30 \\
\hline FL-2065 & Oil & 1 & Coal liquid, direct liquefaction, paraffinic \\
\hline FL-2066 & Solvent & 1 & Blend, paraffinic solvent and methanol \\
\hline Notes: DF $=$ & diesel fuel, 350 ${ }^{\circ}-650^{\circ} F$ & \\
FCC $=$ fluid catalytic cracking & full boiling range material & \\
\hline Oil $=$ & &
\end{tabular}




\section{Flame Luminosity of Ethanol/Methanol Mixtures}

The objective of this work was an examination of the variation of flame luminosity at several ethanol concentrations in mixtures of methanol and ethanol. The experiments were done previously and reported this period. Solutions were prepared, combusted, and rated as described below. All work was carried out in a fume hood with the exhaust fan turned off.

Three stock solutions were made at $25 \mathrm{Vol} \%, 50 \mathrm{Vol} \%$, and $75 \mathrm{Vol} \%$ ethanol in methanol. $5 \mathrm{~mL}$ of each solution and both neat alcohols were individually pipetted into clean petri dishes for combustion. For photometer-rated experiments, one dish was set $50 \mathrm{~cm}$ from the optometer, which was $75^{\circ}$ above the table top with the petri dish at the apex of the angle. For visually-rated experiments, a row of five dishes was placed in the center of the fume hood 5-6 cm apart.

Visually-rated experiments were done by assigning a rating of one unit of brightness to the methanol flame, when viewed in the fume hood with the other flames. These ratings were made in a darkened room. The ethanol flame was assigned a rating of 10 brightness units. The ratings were assigned from a photographic record after all experiments were complete.

The Visual Ratings can be shown as follows:

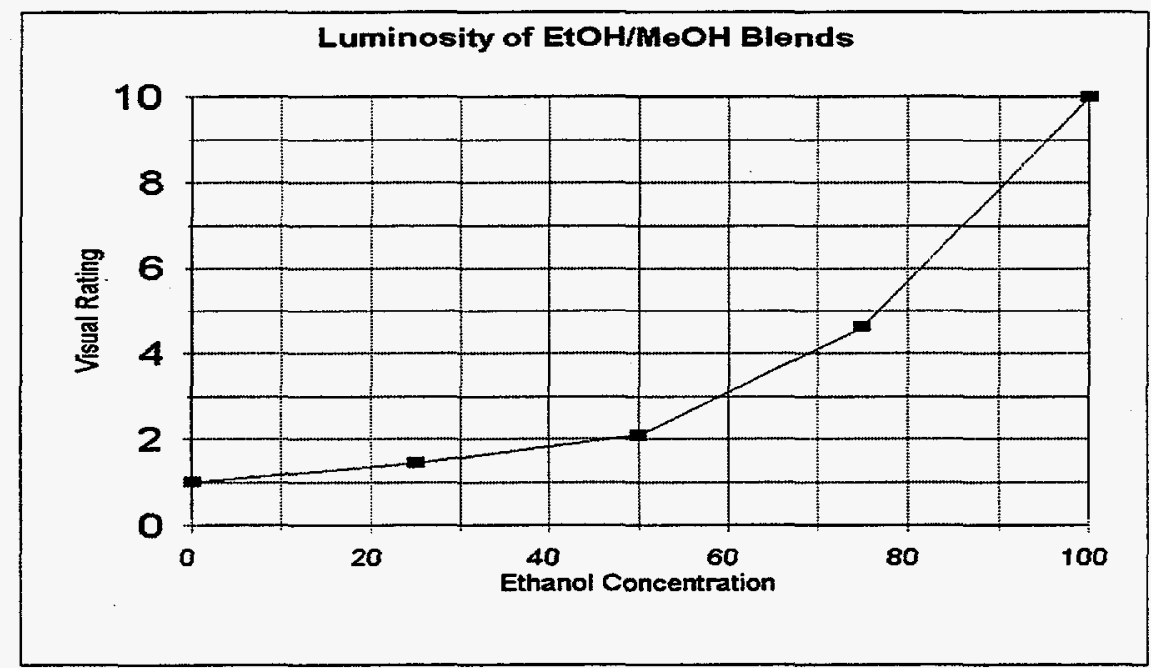

Figure 6. Flame Luminosity of ethanol/methanol mixtures

Similar trends were observed in photometer-rated experiments

Summary - The ethanol dominates the flame luminosity because it contains a carbon-carbon bond, which leads to soot formation in the plasma of the flame. In methanol, there is no carbon-carbon bond, so its flame is free of soot particles, which glow in the heat of the flame, producing black body radiation of many frequencies in the visible range. 


\section{Task 2: Facility Upgrade}

Work on this task is complete, but the following summary is presented as an overview of the recently installed control system and operator interface.

In October, 1993, acquisition of the control system upgrades for the hydrogenation pilot plant began. The hydrogenation pilot plant was constructed 13 years ago by Xytel. Because the computer and control hardware and software had become obsolete with the manufacturers, the pilot plant was experiencing more frequent and serious service interruptions that arose from the control system. Xytel was selected to perform a facility upgrade of the control system because of its experience with several proprietary items on the pilot plant.

The computer upgrade for the pilot plant included the computer/interface hardware, FIX software, and computer system documentation. The control system software that was installed is based on FIX DMACSTM (Version 3.02) software package from Intellution, Inc. The function of the program is System Control and Data Acquisition (SCADA).

The engineering portion of the package contains the following features: it is a menu-driven system and control strategy configuration with on-line help, it has a real-time display builder with mouse support, the program allows set up of password protection, operator entry limits, display linkages, tag groups, and key macros, and set up of historical trending of process variables, and formatting of run-time reports, etc.

In January 1994, the hydrogenation pilot plant control system upgrade was installed on site. Xytel provided a turnkey operation for configuring the system based upon the previous pilot plant system functions. The control system database was created based on the process I/O and control strategies used by Xytel on the many Distributed Manufacturing and Control Software (DMACS) systems they have made. Standard displays were created for the use of the operator to monitor and control the process. Xytel used the C-Data Base Access package to write a custom background program to interface with the weight scales in the system. 


\section{Tasks 3 and 4: Other Government and Industry Research}

The goals of the AFC are to develop higher quality fuels and improve the ability to utilize alternative fuel sources. These goals are advanced through the support of other government and industrial projects that use the AFC. The processing runs for other government programs and industry is shown below in Table 5. In addition to the new alternative fuels knowledge produced over the last 2 years by the AFC project, use of the AFC by other government agencies and industries for outside projects has contributed to better fuels and alternative fuel sources. Further, a regular schedule of pilot plant utilization helps to keep the equipment in good working order. The repair parts purchased on these projects help pay for routine maintenance.

Table 5. Summary of AFC Processing Runs

\begin{tabular}{c|l|l|l|c|c|c}
\hline Run \# & Start & \multicolumn{1}{|c|}{ Feed ID } & Feedstock Description & Sponsor & Product 1 & Product 2 \\
\hline DIST 55 & $7 / 18 / 94$ & FL-2336 & Diesel Component & Oil Company & FL-2353 OH & FL-2354 BT \\
\hline DIST 56 & $7 / 20 / 94$ & FL-2181 & DF2 & “ & FL-2357 OH & FL-2358 BT \\
\hline DIST 58 & $8 / 1 / 94$ & FL-2084 & Diesel Component & “ & FL-2369 OH & FL-2370 BT \\
\hline DIST 59 & $8 / 17 / 94$ & FL-2366 & & US Navy & Trial run & \\
\hline HYDRO 48 & $11 / 7 / 94$ & AL-20573-F & CAT1H & “-2378 OH & FL-2383 OH \\
\hline HYDRO 49 & $11 / 14 / 94$ & FL-2372,2338 & DL1 COAL LIQ, DFT Pet & EndUse Study & Trial run & \\
\hline HYDRO 50 & $11 / 29 / 94$ & FL-2372 & & & \\
\hline HYDRO 51 & $12 / 7 / 94$ & FL-2385,2310 & MN1C coal liq, NTF pet & “ & Trial run & \\
\hline HYDRO 52 & $01 / 18 / 95$ & FL-2385 & DL1 CUT \#3 & “ & FL-2473 & \\
\hline HYDRO 53 & $02 / 24 / 95$ & FL-2385,2310 & DL1 COAL DERIVED & “ & & \\
\hline HYDRO 54 & $03 / 15 / 95$ & FL-2371 & OVHD FROM DIST 57 & “ & & \\
\hline SULFIDING & $11 / 07 / 95$ & H2 Only & CATALYST REGEN & Operations & & \\
\hline
\end{tabular}

The following paragraphs summarize the major government and industry research projects performed this year outside of the AFUP work.

\section{Refining and End-Use Study of Coal Liquids}

The role of coal-derived liquids for domestic transportation fuels is being studied in the DOE program Refining and End Use Study of Coal Liquids at Southwest Research Institute. Both direct- and indirectliquefaction products are in the project. This is one of the three key programs of the DOE Office of Fossil Energy, which also include pilot plant production of "direct" coal liquids by HRI,Inc. in New Jersey and "indirect" liquids by Air Products in La Porte, Texas.

Quantities of gasoline, diesel, and jet fuel will be made for engine tests of performance and emissions from each of three to eight coal liquid feedstocks. The sequence of data gathering, study, sample production and testing is shown in Figure 6 . The first three feedstocks include two coal liquids made by direct liquefaction in which the coal is dissolved in solvent and processed to convert and isolate the components most like petroleum. The third feedstock is from indirect liquefaction where coal is gasified with limited oxygen and the vapors are reacted in Fischer-Tropsch catalyst to form mostly paraffins much as in Germany in the 1940s. 


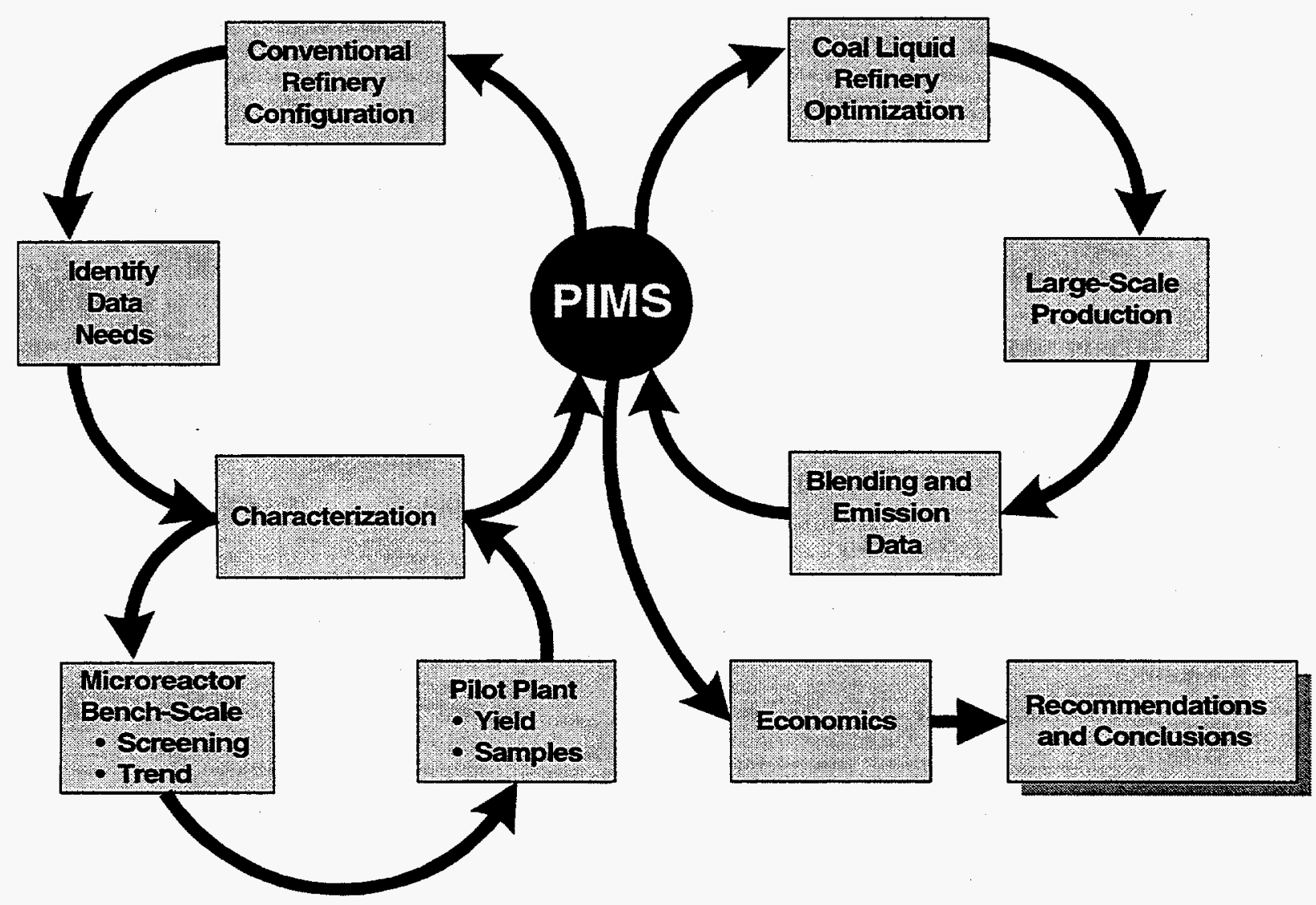

Figure 7. Organization of End Use Study work

It is widely believed that there will never be another US refinery built from scratch, a so-called grassroots facility, much less a dedicated refinery for coal fuel. Therefore, integrating coal liquids into the existing refining system becomes the approach. Questions about what percentage of coal liquid to add and where in the refining process to add it must be answered. The work in the project is outlined on the accompanying drawing, showing the refinery modeling program PIMS at the center.

This program by Bechtel Corporation, the prime contractor, uses linear programming to apportion the many streams of feedstock among the individual processing plants in a refinery that perform the upgrading operations on petroleum. The basic program will first identify an appropriate refinery layout to achieve the needed conversions of coal/petroleum feedstocks to finished fuels. For instance, coal liquids lack the sulfur levels typical of petroleum, requiring less severe treatment to limit sulfur, while direct liquids are high in aromatics that must be directed to the most beneficial place for them in the product slate. A different refinery layout will be chosen for direct and indirect liquids.

Existing data describing petroleum refining operations are inadequate to yield good predictions about refinery performance on the coal liquids, so laboratory tests and pilot plant studies will be made to acquire data for PIMS to come up with recipes for a full slate of refined products. These recipes will be used in Option 1 to produce quantities of test fuels for testing. 
The test matrix will include the usual list of ASTM tests for specification fuels, but will aim at advanced property limits extrapolated to the 2001-2015 time frame. All fuels will then receive single cylinder testing in a variable compression ratio engine (VCR) with limited tests of exhaust emissions at steady-state operating conditions. Selected fuels will go on for modified FIP evaluation in appropriate multicylinder, transient tests.

The future of coal liquids for transportation fuels depends on meeting the ever more restrictive requirements for exhaust emissions such as will be tested in the program, and no fuel source will be adopted without favorable economics. The costs and value of the coal liquids to refining will be investigated as part of the final PIMS model. The specialized composition of indirect coal liquids, being almost entirely paraffins, may hold special promise for diesel fuel quality in the future.

The purpose of this program is twofold: a) to develop fuels that will meet gasoline and diesel fuel specifications for the future in the year 2015 and beyond, and b) to determine how the United States can use its large reserves of coal for transportation fuels. Quantities of gasoline, diesel, and jet fuel will be made for engine tests of performance and emissions from each of three to eight coal liquid feedstocks. The first three feedstocks include two coal liquids made by direct liquefaction in which the coal is dissolved in solvent and processed to convert and isolate the components most like petroleum. The third feedstock is from indirect liquefaction, in which coal is gasified and limited oxygen and the vapors are reacted in Fischer-Tropsch catalyst to form mostly paraffins much as that done in Germany in the 1940s. Because of the prevailing and foreseen limitations on refinery construction and operations, the approach becomes on of integrating coal liquids into the existing refining system. The refinery modeling program PIMS is used to outline the integration process, which may help determine where and in what percentages the coal liquid should be added to the process. Linear programming will be used to apportion the many streams of feedstock among the individual processing plants in the refinery that perform the upgrading operations on petroleum. The costs and value of the coal liquids to refining will be investigated as part of the final PIMS model.

\section{Effect of Refining Severity on the lubricity of NATO F-76 Fuel}

At present, more severely refined fuels are being produced with decreased sulfur and aromatic components in order to reduce vehicle exhaust emissions. Both military and commercial fuel specifications have been revised. The U.S. Environmental Protection Agency (EPA) specified a maximum sulfur content of $0.05 \mathrm{wt} \%$ for diesel fuel, effective 01 October 1993. The California Air Resources Board (CARB) mandated a more stringent requirement of 10 vol\% aromatics, also effective 01 October 1993. In Europe, sulfur content is limited to $0.3 \mathrm{wt} \%$ maximum and is expected to fall to $0.05 \mathrm{wt} \%$ by 1996 . Severe equipment wear has already been reported through use of very low sulfur fuel in Sweden.

The more severe refining processes required to remove sulfur may result in the production of fuels devoid of the reactive components necessary for effective lubrication. A previous U.S. Armysponsored study showed a strong correlation between decreasing sulfur and aromatic content and wear for randomly selected fuels from around the world. ${ }^{2}$ Similarly, increased wear may occur in

${ }^{2}$ Lacey, P.I. "Wear Mechanism Evaluation and Measurement in Fuel-Lubricated Components," BFLRF Report No. 286 (AD A284870), Available from Defense Technical Information Center, Alexandria, Va., September 1994. 
the fuel systems of both ground and marine vehicles that operate with these fuels. Lubricity ${ }^{3}$ additives exist; however, due to variation in additive quality or concentration, no specification for minimum acceptable protection is available.

The primary objective of the Navy project is to define the effects of increasingly severe hydrotreatment (i.e., the refining process used to reduce sulfur and aromatic content) on the lubricity and expected wear resistance of F-76 NATO diesel fuels. A correlation between lubricity and sulfur/aromatic content should result. A secondary objective is to define the effects of humidity, deionized water, salt water contamination, aging, and red dye on lubricity. Following is a description of the test program designed to meet these objectives.

The aim of the study is to use these wear mechanism-specific tests to define the effects of decreasing sulfur and aromatic content on F-76 diesel fuel lubricity. Because the concentrations of sulfur and aromatics are closely related to refining severity, a number of refinery sources will be used in an attempt to broadly define the critical level of refining severity past which fuel system-related wear may be an issue. General properties of these test fuels are given in Table 6. In addition, the correlation between refining severity and lubricity will be examined: Does fuel lubricity decrease linearly with increasing refining severity, or does wear rate increase disproportionately at a critical sulfur/aromatic level? A table summarizing the expected work sequence is provided in Appendix A. The first three tasks have been completed. The remaining tasks are being delayed pending completion of the present test plan and will require approximately 12 months to complete.

Successful completion of this project will allow the U.S. Navy to make informed decisions relating to the effects of reformulated low-sulfur, low-aromatic diesel fuels on the likely durability of fuel handling and injection equipment. Additionally, it may be possible to predict wear resistance indirectly from readily measured chemical or physical properties.

\footnotetext{
${ }^{3}$ In the Navy study, the term "lubricity" is used according to the broad definition provided by Appeldoorn and Dukek (SAE Paper No. 600712, Society of Automotive Engineers, Warrendale, PA, 1966.): "If two liquids have the same viscosity, and one gives lower friction, wear, or scuffing, then it is said to have better lubricity."
} 
TABLE 6. Fuel Samples in Navy Lubricity Study

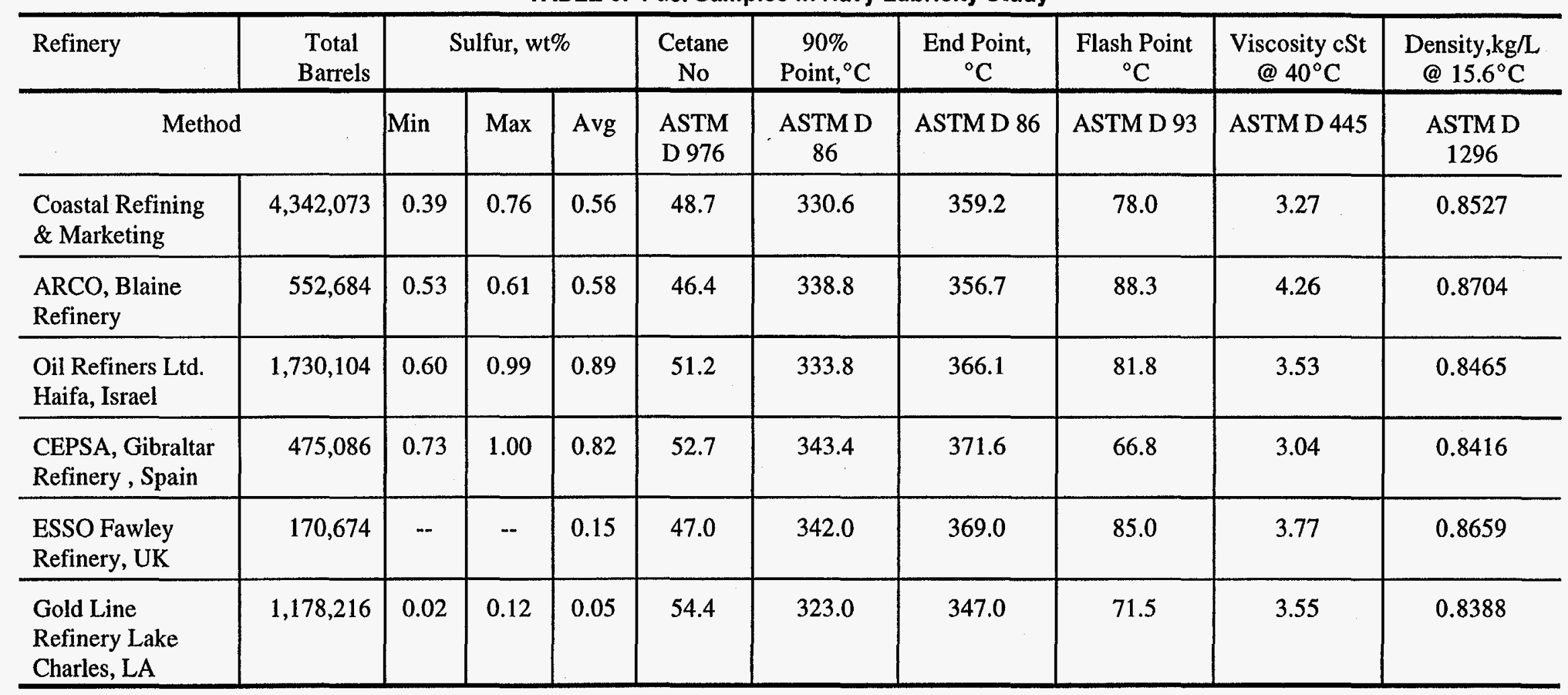




\section{Visitors and Tours}

The DOE AFC received many visitors during the year. Numerous quick stops are not recorded, but Table 7 lists several of the year's notable tours. The exposure to visitors is beneficial for the work of the Center by making known its capabilities and mission. Table 7 does not include the project visits by NREL staff or by the sponsors of the many nearby projects who may stop when they are visiting their work. The international visitors are particularly noteworthy, particularly in the cases where the guest had requested to visit the AFC from having heard about it before their visit.

Table 7. Tours and Visits to DOE Alternative Fuel Center

\begin{tabular}{l|l|c|l}
\hline Date & \multicolumn{1}{|c|}{ Identity } & Number & \multicolumn{1}{c}{ Interest } \\
\hline 29JUL94 & Shell & 1 & Technician Duties \\
\hline 15AUG94 & Antek Instruments & 1 & Online Sulfur Analysis \\
\hline 2NOV94 & Shell Malaysia & 2 & Distillation \\
\hline 14NOV94 & End Use Study Participants & 8 & Project Work in AFC \\
\hline 6MAR95 & Yukong (Korea) & 2 & Pilot Plant Operation \\
\hline 20APR95 & Chevron & 1 & Fixed-Bed Processing \\
\hline 21APR95 & Petronas Research (Malaysia) & 1 & Fuel Properties \\
\hline 25APR95 & Graduate Student & 1 & Tour \\
\hline 11MAY95 & Intevep (Brazil) & 1 & Heat Transfer \\
\hline
\end{tabular}




\section{Task 5: Health and Safety Compliance}

Health and safety aspects of all AFC maintenance and operations were closely monitored over the past year. No formal noncompliance issues with any local, state, or federal entities resulting from this work occurred over the contract year. Normal 'wear and tear' of the building monitoring systems have resulted in malfunctioning sensors, as noted in Table 2. A plan for reinstating these functions is in progress. 


\section{Conclusions}

The AFC equipment was maintained in ready-to-operate working order in the reporting period.

The AFC test fuel sample inventory has been maintained in good order this year.

Flame luminosity of ethanol/methanol mixtures is dominated by the ethanol concentration in all concentration ranges.

Outside processing interests have shifted from the rush of efforts fro environmental regulation compliance more toward refinery process improvement and new processes.

Capabilities to serve AFUP was augmented through outside work and the installation of new sensors and mass balance capabilities, including:

- Sulfur and nitrogen mass balances

- Improved accuracy of overall mass balances.

Installation of a new, small ( 1 liter) reactor, providing enhanced functions, among which are:

- Scoping studies at low flow rates, typically 0.25 gallons per hour, using the same conditions, if desired, as available at the higher rates (up to about 4 gallons per hour)

- With preferred reactor geometry, maximum specific processing rate to 12 LHSV (up from 2.8), useful for reactions occurring faster than most conventional petroleum processing

Beyond the specific alternative fuels data produced this year by the AFC project, the continued interest in the AFC by other government agencies and industries for participation in their research, is a further product of the AFUP. In promoting its own program, the AFUP is furthering knowledge of and preparedness for alternative transportation fuels by aligning with the research of other organizations pursuing parallel missions. 
Exhibit 1. Index of Monthly Progress Reports 
XS-2-12130-1 Summary of Monthly Progress Reports (01-5151) Year 3

\begin{tabular}{l|c|c|c|c|c|c|c|c|c|c|c|c}
\hline Iopics & 25 & 26 & 27 & 28 & 29 & 30 & 31 & 32 & 33 & 34 & 35 & 36 \\
\hline Maintenance & $\bullet$ & & & & $\bullet$ & $\bullet$ & & & $\bullet$ & $\bullet$ & $\bullet$ & $\bullet$ \\
\hline Outside Processing & $\bullet$ & $\bullet$ & $\bullet$ & F4 & $\bullet$ & $\bullet$ & $\bullet$ & $\bullet$ & $\bullet$ & $\bullet$ & & \\
\hline Modification & $\bullet$ & & & & & & F1 & & & & & \\
\hline Small Reactor & & $\bullet$ & $\bullet$ & $F 1$ & & & & F1 & & & & \\
\hline Luminosity Study & & $\bullet$ & & & F1 & & & & & & & \\
\hline Mass Balance & & & $\bullet$ & & & & & & F1 & & $\bullet$ & \\
\hline Visitor and Tours & & & $\bullet$ & & $\bullet$ & & $\bullet$ & $\bullet$ & & & & \\
\hline Travel/Contacts & & & & & & $\bullet$ & & & & & & \\
\hline
\end{tabular}

$\begin{array}{ll}- & \text { Topic covered } \\ \text { F } & \text { Figure (number) }\end{array}$

XS-2-12130-1 Summary of Monthly Progress Reports (01-5151) Year 2

\begin{tabular}{|c|c|c|c|c|c|c|c|c|c|c|c|c|}
\hline Topics & 13 & 14 & 15 & 16 & 17 & 18 & 19 & 20 & 21 & 22 & 23 & 24 \\
\hline Sample Inventory & - & & & & & & & & $\mathrm{T} 2$ & & & \\
\hline Maintenance & & - & - & 을 & e & e & & & e & e & & \\
\hline Travel/Contacts & & & & - & & & & & & & & \\
\hline Outside Processing & 으 & & e & & & 으 & - & - & - & - & - & - \\
\hline $\begin{array}{l}\text { Low Reactivity/ } \\
\text { Emissions Gasoline }\end{array}$ & • & & & & & & & & & & & \\
\hline Visitor and Tours & & & & & & & & - & 은 & & 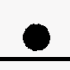 & - \\
\hline Control Upgrade & & e & e & - & - & $F 1-5$ & - & & e & & & \\
\hline Ethanol RVP & & & & - & - & & & & & & & \\
\hline Small Reactor & & & & & & e & & & & & & \\
\hline Schedule & & & & & & & & & $\mathrm{T} 1$ & $\mathrm{~T}$ & & \\
\hline
\end{tabular}

\begin{tabular}{cl}
\hline- & Topic covered \\
$\mathrm{T}$ & Table (number) \\
$\mathrm{F}$ & Figure (number) \\
\hline
\end{tabular}


XS-2-12130-1 Summary of Monthly Progress Reports (01-5151) Year 1

\begin{tabular}{|c|c|c|c|c|c|c|c|c|c|c|c|c|}
\hline Topics & 1 & 2 & 3 & 4 & 5 & 6 & 7 & 8 & 9 & 10 & 11 & 12 \\
\hline Sample Inventory & & & & & & & & & & eT & 우 & \\
\hline Maintenance Log & 0 & & - & & & & & - & e & 0 & - & 0 \\
\hline Equipment Custody & & & & & - & & & & & & & \\
\hline $\begin{array}{l}\text { Hydrotreat Cracked } \\
\text { Gasoline }\end{array}$ & & - & $\bullet$ & - & & & & & & & & \\
\hline Travel/Contacts & & & & & - & & & & & & & \\
\hline Outside Processing & & & & - & - & & - & - & - & $T$ & 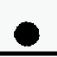 & - \\
\hline $\begin{array}{l}\text { Hydrogen Trailer \& } \\
\text { Pilot Plant } \\
\text { Components }\end{array}$ & & & $\bullet$ & - & & - & - & & & - & - & - \\
\hline $\begin{array}{l}\text { Low Reactivity/ } \\
\text { Emissions Gasoline }\end{array}$ & - & 0 & $\bullet$ & - & - & & & & & & & \\
\hline Visitor and Tours & & & & & & & & & 은 & 은 & 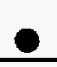 & - \\
\hline Environmental Safety & - & 은 & ? & 을 & e & e & e & 은 & 0 & 으 & e & - \\
\hline Control Upgrade & e & & e & - & 은 & 으 & e & 은 & e & e & e & P \\
\hline
\end{tabular}

Note: Reference Month 1 = August 1993

\begin{tabular}{ll}
- & Topic covered \\
$T$ & Table (number) \\
$F$ & Figure (number) \\
\hline
\end{tabular}


Exhibit 2. Annual Government Property Inventory 


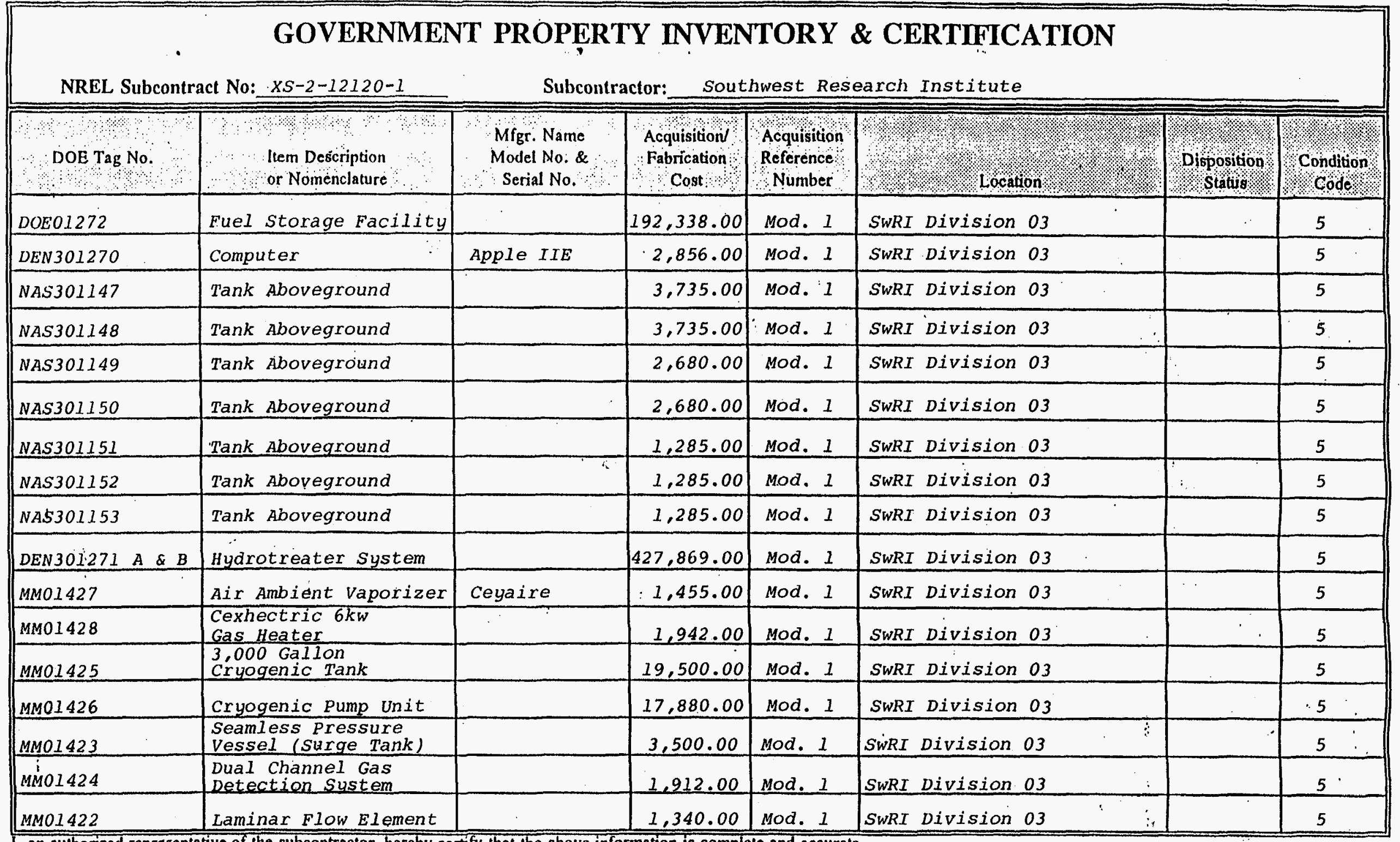

I, an authorized representative of the subcontractor, hereby certify that the above information is complete and accurate.

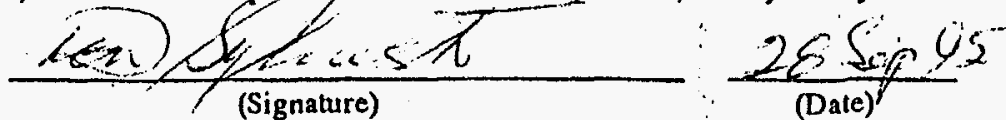

Don sylvester

(Date)

(Printed Name)

Property Administrator

(Title) 


\begin{tabular}{|c|c|c|c|c|c|c|c|}
\hline \multicolumn{8}{|c|}{ GOVERNMENT PROPERTY INVENTORY \& CERTIFICATION } \\
\hline \multicolumn{2}{|c|}{ NREL Subcontract No: $\quad X S-2-12120-1$} & \multicolumn{5}{|c|}{ Subcontractor: Southwest Research Institute } & \multirow[b]{2}{*}{ Condition } \\
\hline DOE Tag No. & $\begin{array}{l}\text { Item Description } \\
\text { or Nomenclature }\end{array}$ & $\begin{array}{c}\text { Mfgr. Name } \\
\text { Model No. \& } \\
\text { Serial No. }\end{array}$ & $\begin{array}{l}\text { Acquisition/ } \\
\text { Fabrication } \\
\text { Coost }\end{array}$ & $\begin{array}{l}\text { Acquisition } \\
\text { Reference } \\
\text { Number }\end{array}$ & ४ & Disposition & \\
\hline$N / A$ & $\begin{array}{l}\text { Valve, Excess } \\
\text { Flowcheck }\end{array}$ & & 125.00 & Mod, 1 & SWRI Division 03 & & 5 \\
\hline$N / A$ & Gas Detector & & 193.00 & Mod. 1 & SWRI Division 03 & & 5 \\
\hline$N / A$ & Hard Disk Drive & Vulcan & 499.00 & Mod. $i$ & SWRI Division 03 & & 5 \\
\hline$N / A$ & Charge Amplifier & $504 E$ & 685.00 & Mod. 1 & SWRI Division 03 & & 5 \\
\hline$N / A$ & $\begin{array}{l}\text { Each } \\
\text { Pressure Transducer }\end{array}$ & $12 \mathrm{AP} 300 \mathrm{CVK}$ & $1,600.00$ & Mod. 1 & SWRI Division 03 & & 5 \\
\hline$N / A$ & Power Supply 4 Amp & & 217.00 & Mod. 1 & SWRI Division 03 & & 5 \\
\hline$N / A$ & Pump MB4I & & 208.00 & Mod. 1 & SWRI Division 03 & & 5 \\
\hline$N / A$ & Heat ExChanger BCF & & 479.00 & Mod. 1 & SWRI Division 03 & & 5 \\
\hline$N / A$ & $\begin{array}{l}\text { Data General } 4222 \\
\text { Digital Interface }\end{array}$ & & 400.00 & Mod. 1 & SWRI Division 03 & & 5 \\
\hline$N / A \quad:$ & Pressure Regulator & $H 2 H 50$ & 115.00 & Mod. 1 & SWRI Division 03 & & 5 \\
\hline$N / A$ & Circulation Heat & $\mathrm{CCH}-21005$ & 313.00 & Mod. 1 & SWRI Division 03 & & 5 \\
\hline$N / A$ & Rotameter & $110-24$ & 842.00 & Mod. 1 & SWRI Division 03 & & 5 \\
\hline$N / A$ & $\begin{array}{l}\text { Timing Light } \\
\text { Transducer }\end{array}$ & $7080-012$ & 180.00 & Mod. 1 & SWRI Division 03 & & 5 \\
\hline$N / A$ & Doric Controller & $D C-7025-L$ & 395.00 & Mod. 1 & SWRI Division 03 & & 5 \\
\hline$N / A$ & Injector Pump & & 450.00 & Mod. 1 & SWRI Division 03 & & 5 \\
\hline$N Y A$ & Storage Cabinet & $\begin{array}{l}\text { Grainger } \\
3 \text { we } 43\end{array}$ & 161.00 & Mod. 1 & SWRI Division 03 & & 5 \\
\hline$N / A$ & Filing Cabinet & $14121 C L-D S$ & 53.00 & Mod. 1 & SWRI Division 03 & & 5 \\
\hline
\end{tabular}

I, an authorized representative of the subcontractor, hereby certify that the above information is complete and accurate.

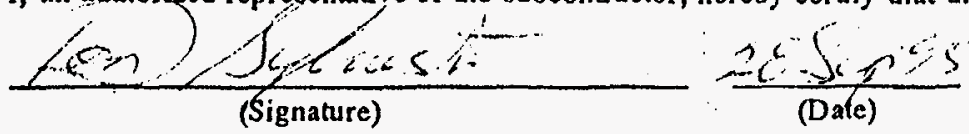

Don Sylvester

Property Administrator

(Printed Name)

(Title) 


\begin{tabular}{|c|c|c|c|c|c|c|c|}
\hline \multicolumn{8}{|c|}{ GOVERNMENT PROPERTY INVENTORY \& CERTIFICATION } \\
\hline \multicolumn{2}{|c|}{ NREL Subcontract No: $\quad x S-2-12120-1$} & \multicolumn{4}{|c|}{ Subcontractor: Southwest Research Institute } & \multirow[b]{2}{*}{ 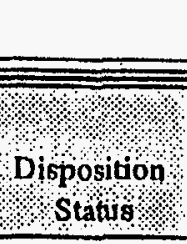 } & \multirow[b]{2}{*}{$\begin{array}{r}\text { Conditon } \\
\text { Codele } \\
\end{array}$} \\
\hline DOE Tag No. & $\begin{array}{l}\text { them Description } \\
\text { Oor Nomenclature }\end{array}$ & $\begin{array}{l}\text { MGgr. Name } \\
\text { Model No. \& } \\
\text { Serial No. }\end{array}$ & $\begin{array}{l}\text { Acquistition } \\
\text { Fabrication } \\
\text { Cost }\end{array}$ & $\begin{array}{l}\text { Acquistition } \\
\text { Reference } \\
\text { Number }\end{array}$ & (l) & & \\
\hline$N / A$ & Blower W/Motor & & 320.00 & Mod. 1 & SWRI Division $0_{3}$ & & 5 \\
\hline$N / A$ & \begin{tabular}{|l} 
Pressure Regulating \\
Valve
\end{tabular} & & 400.00 & Mod. 1 & SWRI Division 03 & & 5 \\
\hline & $\because$ & & & & & & \\
\hline & & & & & & & \\
\hline & & & & & & & \\
\hline & & & & & & & \\
\hline & & & & & & & \\
\hline & & & & & & & \\
\hline 1 & & & & & & & \\
\hline$\vdots$ & & & & & & & \\
\hline & & & & & & & \\
\hline & & & & & & & \\
\hline & & & & I & & & \\
\hline & & & & & & & $\therefore$ \\
\hline & & & & & & & \\
\hline i & & & & & & & 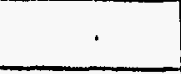 \\
\hline & & & & & & & \\
\hline
\end{tabular}

I, gn authonized representative of the subcontractor, hereby certify that the above information is complete and accurate.

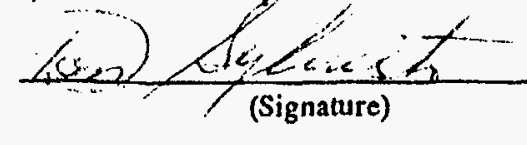

Den sulvester

(Printed Name) $\frac{-22-5(2) \cdot(5)}{\text { (Date) }}$

property Administrator

(Title) 
Exhibit 3. Description of Facilities 


\section{FACILITIES DESCRIPTION US DOE ALTERNATIVE FUEL CENTER AT SOUTHWEST RESEARCH INSTITUTE}

The Synthetic Fuel Center (SFC) was established by the Department of Energy (DOE) as part of the Alternative Fuels Utilization Program (AFUP) to provide drum quantities of finished transportation fuels from a variety of sources. Since 1978 the AFUP of the Office of Energy Efficiency and Renewable Energy has investigated the possibilities and limitations of expanded scope and replacement means for transportation fuels from alternative sources to complement conventional petroleum fuels. The main function was to provide test fuels in 5- to 500-gallon quantities for research projects on the utilization of alternative fuels.

DOE funded the design, construction, and installation of a hydrogenation pilot plant capable of performing a range of hydrotreating, reforming, and hydrocracking operations. SwRI provided the building, utilities, and laboratory and safety systems needed for the pilot plant. Later, the U.S. Navy provided a pilot-scale continuous

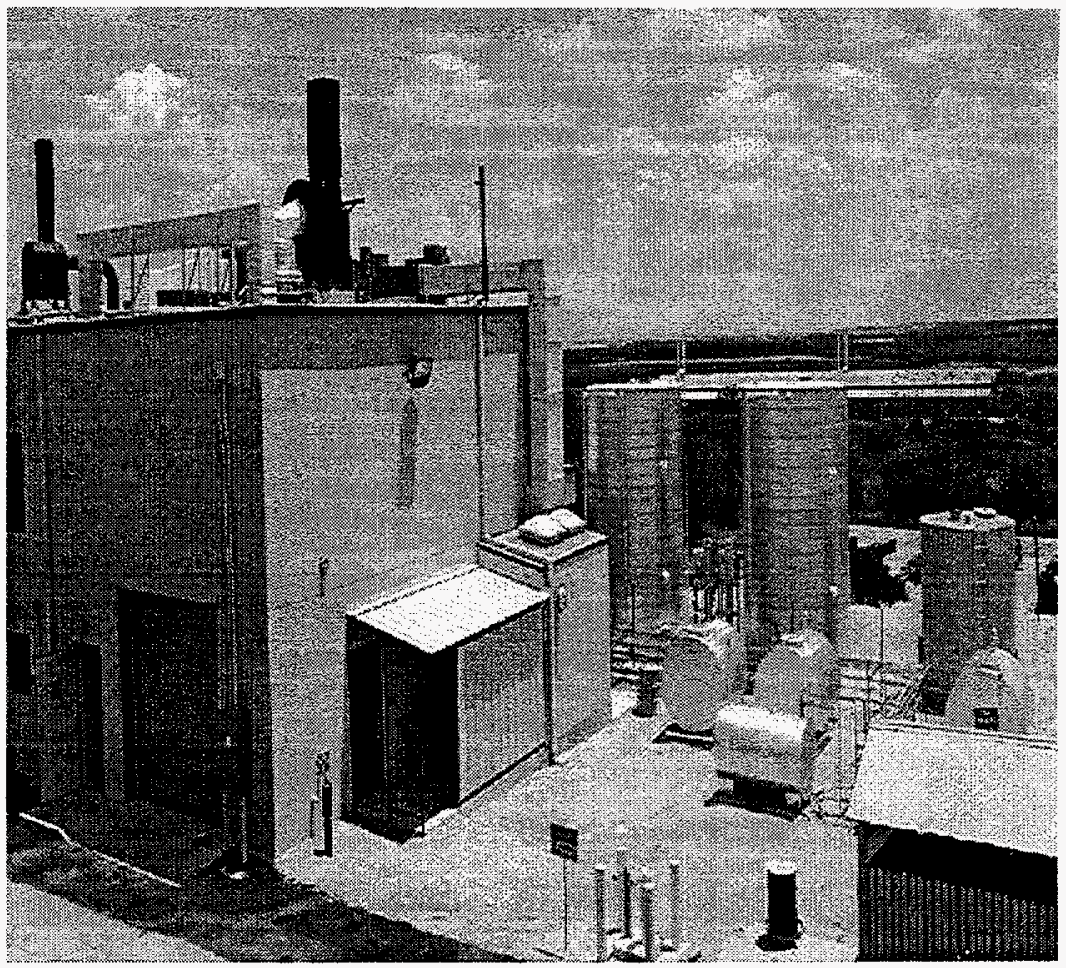

US DOE ALTERNATIVE FUEL CENTER distillation unit, and SwRI provided batch distillation equipment, which are conveniently housed in the same building as the hydrotreater pilot plant, but are not formally part of the AFC

The AFC is comprised of samples, structures, equipment, and storage infrastructure on a specially diked work area spread over about an acre at Southwest Research Institute. Descriptions of the facilities are provided in the following sections. 


\section{HYDROGENATION UNIT CAPABILITIES}

The pilot unit was designed with flexibility to handle a range of hydrogenation operations. Nominal feed rate is 1.0 to $2.2 \mathrm{gal} / \mathrm{hr}$. The reactor section operates at pressures to $3000 \mathrm{psig}$ and temperatures to $1000^{\circ} \mathrm{F}$. Hydrogen circulation capacity of $250 \mathrm{scf}$ per hour is equivalent to about $4.800 \mathrm{scf}$ per barrel at maximum feed rate. Appropriate operating conditions and catalyst types can be selected for the following product objectives at various levels of severity:

\section{SEVERITY}

Low

Moderate

Intermediate

High

High

\section{PRODUCT OBJECTIVE}

Hydrotreat to reduce sulfur and nitrogen content of reformer feed or distillate fuel.

Hydrotreat to prepare feedstocks for hydrocracking or to increase hydrogen content of fuel.

Hydrogenate aromatics to produce low-emission diesel fuel.

Hydrocrack light cycle oil to make high energy density jet fuel.

Catalytic reforming of low octane naphtha.

The attached process schematic of the unit shows feed joined by hydrogen through a preheater to two fixed-bed reactors in series. Reactor effluent is cooled and liquid product is recovered in two stages of separation. Recycle hydrogen and vent gases are scrubbed to remove contaminants. The liquid product goes to a distillation column, which is used as a stripper to remove $\mathrm{H}_{2} \mathrm{~S}$ or adjust the flash point. Alternatively, the distillation column can take a light product overhead at atmospheric pressure or under vacuum. The column bottoms may be collected as product or recycled to the reactor section. The recycle pump can also be used to increase total feed rate to $3.5 \mathrm{gal} / \mathrm{hr}$

\section{Continuous Fractionation Unit}

A pilot scale Continuous Distillation Apparatus is available for research projects with 1- to 5-day run times. The distillation equipment was funded by the U.S. Navy Air Propulsion Center in cooperation with the U.S. Army Belvoir Research and Development \& Experimental Center. The facility is housed in the Synthetic Fuel Center on the grounds at SwRI and includes all tankage lines, pumps, heat exchangers, and automatic controls for independent operation. The column has the capacity to fractionate approximately $120 \mathrm{gal} /$ day of distillable feed, producing overhead products in the range of $10 \%$ to $90 \%$ of the feed, with the remainder as bottoms product. The column is also equipped for vacuum distillation. Column specifications are: 
Column Type:

packing

Pressure Range:

Temp. Range:

vacuum)

Feed Rate:

$\mathrm{gal} / \mathrm{hr}$

Overhead Product:

Reflux Ratio:

$5: 1)$

Theoretical Plates:

(depending on operating conditions, packing)

The distillation system is designed for unattended fractionation of feedstocks over the range of operating conditions listed above. Process control and data acquisition is through a dedicated microcomputer system linked directly to the process. A sophisticated safety system is part of the operating program and contains dissimilar alarm logic to provide, on one level, troubleshooting actions, and on a higher level, controlled system shutdown. Feed enters the column via a preheater through any of five ports. Light product is condensed overhead and directed back to the column as reflux or to the overhead product receiver. Bottoms product is drawn from the reboiler at the bottom of the column as the level in the reboiler rises.

\section{TEST FUEL CUSTODY AND STORAGE}

Control and preservation of the test fuels produced and acquired for the AFUP is a prime concern. Avariety of large and small storage options were incorporated in the AFC. These storage methods are designed for efficiency in providing physical security for samples being retained including protection from loss, water, heat, oxidation, and contamination.

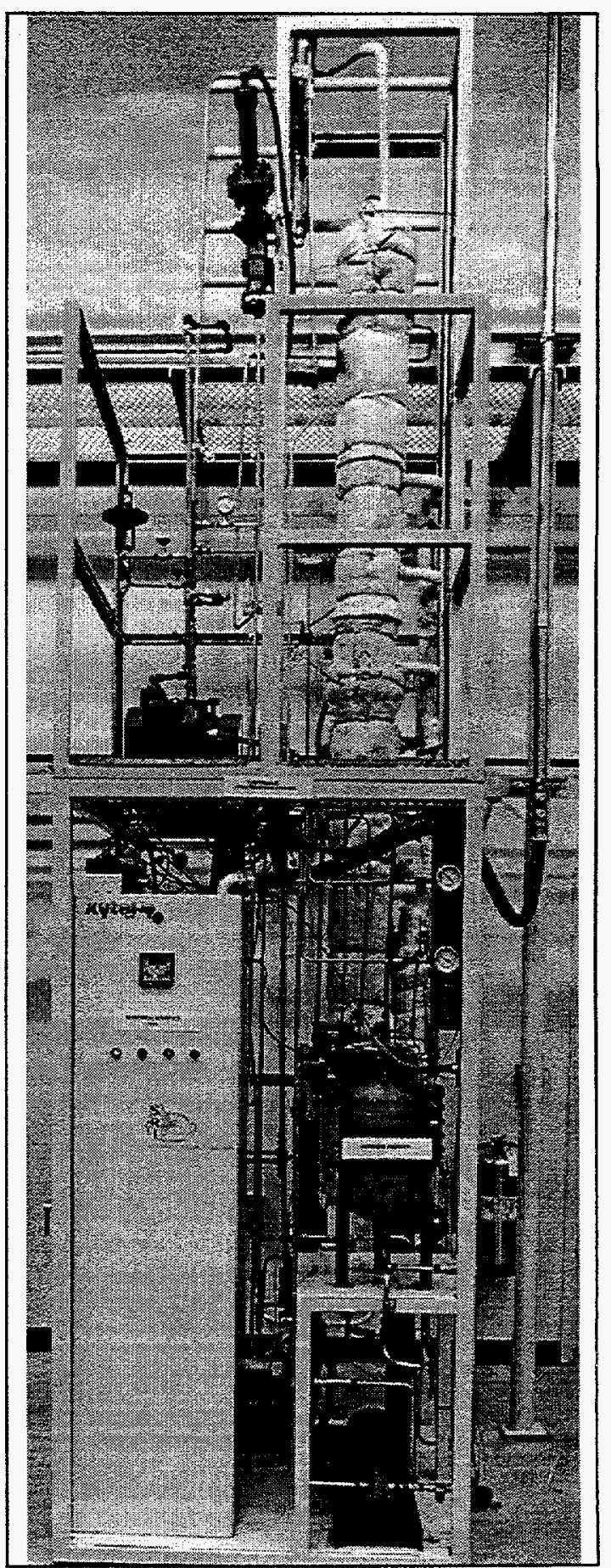

Continuous Fractionation Pilot Plant.

For large samples, a suite of tanks is available. These vessels are interconnected via a pipeway providing filling, draining, vapor return, inerting, temperature sensing, and level measurement. The tanks include:

- 2 Insulated Tanks, 10000 gallon 
- 2 Covered Tanks, 5000 gallon

- 3 Tanks, 1000 gallon

- 4 Tanks, 500 gallon

Additionally there are small mobile tanks for transport and blending, which may be held on weighing scales. With stationary and mobile transfer pumps, a variety of on site blending and handling duties may be performed, including

- Precision Blending

- Sample Transfer

- Filtration

- Clay Treating

- Water Separation

Drum storage in a large, outdoor storage area is available. The location is diked for spill protection and organized by a locator grid for sapmle placement. Limited, refrigerated indoor storage is also available. Small samples are retained in ventillated, indoor storage.

All stored materials are recorded in a sample tracking system to maintain custody. Origin and volumes are kept along with information about MSDS and use in local research. Together with comprehensive laboratory facilities, any storage and analysis requirement can be met. 
Public reporting burden for this collection of information is estimated to average 1 hour per response, including the time for reviewing instruclions, searching existing data sources, gathering and maintaining the data needed, and completing and reviewing the collection of information. Send comments regarding this burden estimate or any other aspect of this collection of information, including suggestions for reducing this burden, to Washington Headquarters Services, Directorate for Information Operations and Reports, 1215 Jefferson Davis Highway, Suite 1204, Arlington, VA 22202-4302, and to the Office of Management and Budget, Paperwork Reduction Project (0704-0188), Washington, DC 20503.

\begin{tabular}{|l|l|l|}
\hline 1. AGENCY USE ONLY (Leave blank) & $\begin{array}{c}\text { 2. REPORT DATE } \\
\text { April } 1996\end{array}$ & $\begin{array}{r}\text { 3. REPORT TYPE AND DATES COVERED } \\
\text { Subcontract report: August 5, 1994-August 4, 1995 }\end{array}$ \\
\hline
\end{tabular}

\section{TITLE AND SUBTITLE}

Maintenance and Operation of the U.S. DOE Alternative Fuel Center. Final Report
5. FUNDING NUMBERS

(C) XS-2-12130-1

(TA) FU621010

6. AUTHOR(S)

J. Enwin and D.S. Moulton

7. PERFORMING ORGANIZATION NAME(S) AND ADDRESS(ES)

8. PERFORMING ORGANIZATION REPORT NUMBER

Southwest Research Institute

P.O. Drawer 28510

DE96007865

San Antonio, TX 78228-0510

9. SPONSORINGMONITORING AGENCY NAME(S) AND ADDRESS(ES)

10. SPONSORING/MONITORING AGENCY REPORT NUMBER

National Renewable Energy Laboratory

1617 Cole Boulevard

NAELTP-425-21083

Golden, CO 80401-3393

\section{SUPPLEMENTARY NOTES}

12a. DISTRIBUTION/AVAILABILITY STATEMENT

National Technical information Service

U.S. Department of Commerce

5285 Port Royal Road

Springfield, VA 22161

13. ABSTRACT (Maximum 200 words) The Alternative Fuel Center (AFC) was established by the U.S. Department of Energy (DOE) as part of the Alternative Fuel Utilization Program (AFUP). The AFC is designed to provide drum quantities of finished transportation fuels from a variety of sources. DOE funded the design, construction, and installation of a hydrogenation pilot plant capable of performing a range of hydrotreating, reforming, and hydrocracking operations. Southwest Research Institute provided the building, utilities, and laboratory and safety systems needed for the pilot plant. The AFC work reported here contributes to the two primary objectives of the AFUP: data for alternative-fuel-capable vehicles to enhance our energy security, and data for controlling emissions for improved air quality.

\begin{tabular}{|c|c|c|c|}
\hline \multirow{2}{*}{\multicolumn{3}{|c|}{$\begin{array}{l}\text { 14. SUBJECT TERMS } \\
\text { Alternative fuels and transportation fuels }\end{array}$}} & \multirow{2}{*}{$\begin{array}{l}\text { 15. NUMBER OF PAGES } \\
34 \\
\text { 16. PRICE CODE }\end{array}$} \\
\hline & & & \\
\hline $\begin{array}{l}\text { 17. SECURITY CLASSIFICATION } \\
\text { OF REPORT }\end{array}$ & $\begin{array}{l}\text { 18. SECURITY CLASSIFICATION } \\
\text { OF THIS PAGE }\end{array}$ & $\begin{array}{l}\text { 19. SECURITY CLASSIFICATION } \\
\text { OF ABSTRACT }\end{array}$ & 20. LIMITATION OF ABSTRACT \\
\hline
\end{tabular}



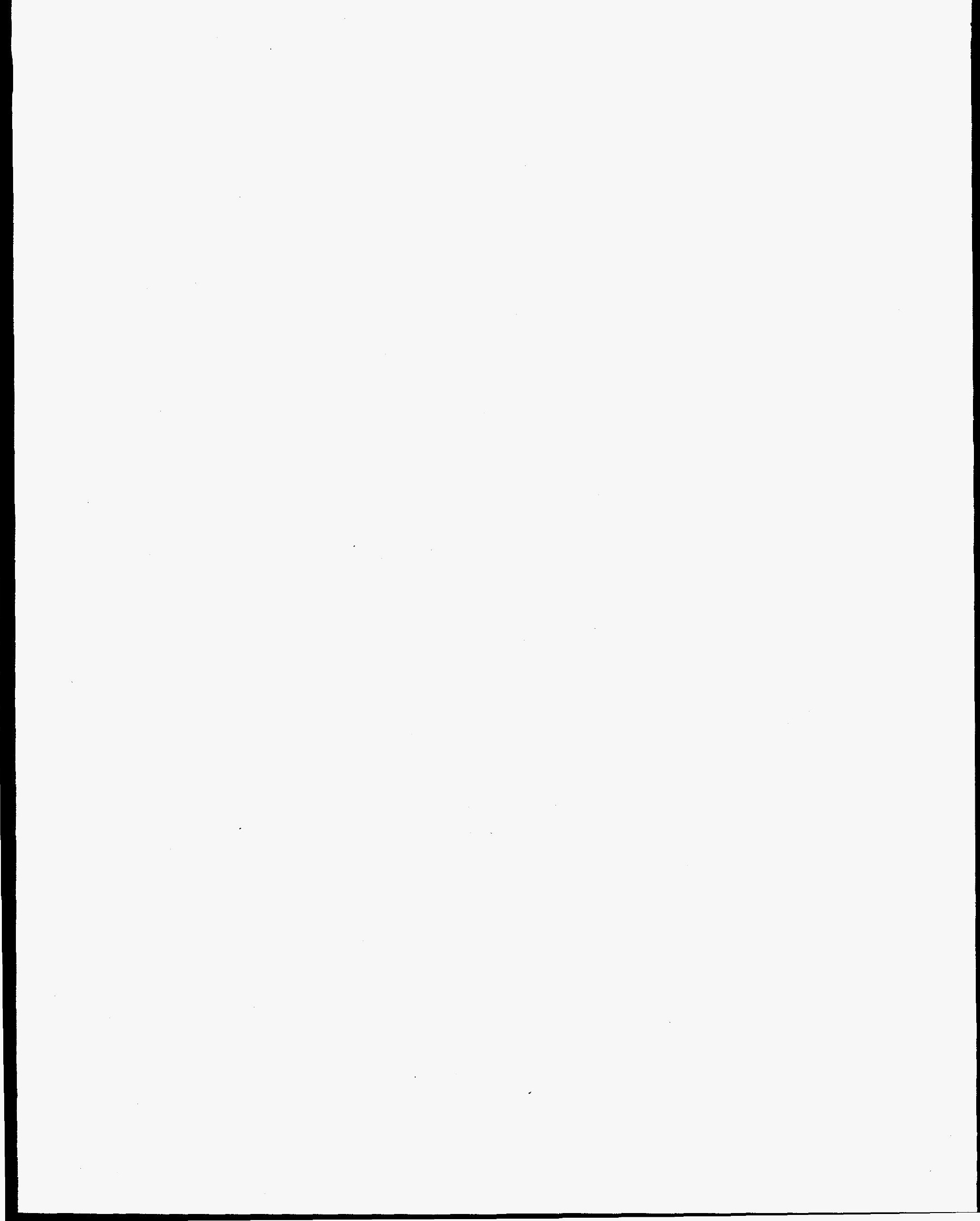